\title{
Aerosol meteorology of Maritime Continent for the 2012 7SEAS southwest monsoon intensive study - Part 2: Philippine receptor observations of fine-scale aerosol behavior
}

Jeffrey S. Reid ${ }^{1}$, Nofel D. Lagrosas ${ }^{2}$, Haflidi H. Jonsson ${ }^{3}$, Elizabeth A. Reid ${ }^{1}$, Samuel A. Atwood ${ }^{4}$, Thomas J. Boyd ${ }^{5}$, Virendra P. Ghate $^{6}$, Peng Xian ${ }^{1}$, Derek J. Posselt ${ }^{7}$, James B. Simpas ${ }^{2}$, Sherdon N. Uy ${ }^{2}$, Kimo Zaiger ${ }^{8}$, Donald R. Blake ${ }^{9}$, Anthony Bucholtz ${ }^{1}$, James R. Campbell ${ }^{1}$, Boon Ning Chew ${ }^{10}$, Steven S. Cliff ${ }^{11}$, Brent N. Holben ${ }^{12}$, Robert E. Holz ${ }^{13}$, Edward J. Hyer ${ }^{1}$, Sonia M. Kreidenweis ${ }^{4}$, Arunas P. Kuciauskas ${ }^{1}$, Simone Lolli ${ }^{14}$, Min Oo ${ }^{13}$, Kevin D. Perry ${ }^{15}$, Santo V. Salinas ${ }^{16}$, Walter R. Sessions ${ }^{13}$, Alexander Smirnov ${ }^{17}$, Annette L. Walker ${ }^{1}$, Qing Wang ${ }^{3}$, Liya $\mathrm{Yu}^{18}$, Jianglong Zhang ${ }^{19}$, and Yongjing Zhao ${ }^{11}$

${ }^{1}$ Marine Meteorology Division, Naval Research Laboratory, Monterey, CA, USA

${ }^{2}$ Manila Observatory, Manila, Philippines

${ }^{3}$ Department of Meteorology, Naval Postgraduate School, Monterey, CA, USA

${ }^{4}$ Dept. of Atmospheric Science, Colorado State University, Ft. Collins, CO, USA

${ }^{5}$ Marine Biogeochemistry Section, Naval Research Laboratory, Washington, DC, USA

${ }^{6}$ Argonne National Laboratory, Argonne, IL, USA

${ }^{7}$ Dept. of Atmospheric, Oceanic, and Space Sciences, University of Michigan, Ann Arbor, MI, USA

${ }^{8}$ NAVFAC Engineering and Expeditionary Warfare Center Port Hueneme, CA, USA

${ }^{9}$ Dept. of Chemistry, University of California, Irvine, CA, USA

${ }^{10}$ Meteorological Service, Singapore

${ }^{11}$ Department of Applied Science, University of California Davis, CA, USA

${ }^{12}$ NASA Goddard Space Flight Center, Greenbelt, MD, USA

${ }^{13}$ Space Science Engineering Center, University of Wisconsin, Madison, WI, USA

${ }^{14}$ University of Maryland Baltimore County-JCET, Baltimore, MD, USA

${ }^{15}$ University of Utah, Salt Lake City, UT, USA

${ }^{16}$ Centre for Remote Imaging Sensing and Processing, National University of Singapore, Singapore

${ }^{17}$ Science Systems and Applications, Inc., Lanham, MD, USA

${ }^{18}$ Dept. of Environmental Engineering, National University of Singapore, Singapore

${ }^{19}$ Dept. of Atmospheric Science, University of North Dakota, Grand Forks, ND, USA

Correspondence to: Jeffrey S. Reid (jeffrey.reid@nrlmry.navy.mil)

Received: 11 March 2016 - Published in Atmos. Chem. Phys. Discuss.: 25 April 2016

Revised: 2 September 2016 - Accepted: 2 October 2016 - Published: 15 November 2016

\begin{abstract}
The largest 7 Southeast Asian Studies (7SEAS) operations period within the Maritime Continent (MC) occurred in the August-September 2012 biomass burning season. Data included were observations aboard the M/Y Vasco, dispatched to the Palawan Archipelago and Sulu Sea of the Philippines for September 2012. At these locations, the Vasco observed MC smoke and pollution entering the southwest
\end{abstract}

monsoon (SWM) monsoonal trough. Here we describe the research cruise findings and the finer-scale aerosol meteorology of this convectively active region. This 2012 cruise complemented a 2-week cruise in 2011 and was generally consistent with previous findings in terms of how smoke emission and transport related to monsoonal flows, tropical cyclones (TC), and the covariance between smoke transport events and 
the atmosphere's thermodynamic structure. Biomass burning plumes were usually mixed with significant amounts of anthropogenic pollution. Also key to aerosol behavior were squall lines and cold pools propagating across the South China Sea (SCS) and scavenging aerosol particles in their path. However, the 2012 cruise showed much higher modulation in aerosol frequency than its 2011 counterpart. Whereas in 2011 large synoptic-scale aerosol events transported high concentrations of smoke into the Philippines over days, in 2012 measured aerosol events exhibited a much shorter-term variation, sometimes only $3-12 \mathrm{~h}$. Strong monsoonal flow reversals were also experienced in 2012. Nucleation events in cleaner and polluted conditions, as well as in urban plumes, were observed. Perhaps most interestingly, several cases of squall lines preceding major aerosol events were observed, as opposed to 2011 observations where these lines largely scavenged aerosol particles from the marine boundary layer. Combined, these observations indicate pockets of high and low particle counts that are not uncommon in the region. These perturbations are difficult to observe by satellite and very difficult to model. Indeed, the Navy Aerosol Analysis and Prediction System (NAAPS) simulations captured longer period aerosol events quite well but largely failed to capture the timing of high-frequency phenomena. Ultimately, the research findings of these cruises demonstrate the real world challenges of satellite-based missions, significant aerosol life cycle questions such as those the future Aerosol/Clouds/Ecosystems (ACE) will investigate, and the importance of small-scale phenomena such as sea breezes, squall lines, and nucleation events embedded within SWM patterns in dominating aerosol life cycle and potential relationships to clouds.

\section{Introduction and background}

The 7 Southeast Asian Studies (7SEAS) program has motivated observations of the Maritime Continent (MC) aerosol environment that have led to significant advances in understanding the region's aerosol life cycle and climate impacts (Reid et al., 2012, 2013; Lin et al., 2013). While linkages between biomass burning and the El Niño/Southern Oscillation (ENSO) have long been identified for this region (e.g., Nichol, 1998; Field and Shen, 2008), the relative importance of the Madden-Julian Oscillation (MJO), equatorial waves, tropical cyclones (TCs), and even features as fine scale as boundary layer dynamics and squall lines have been recently connected to aerosol life cycle (e.g., Reid et al., 2012, 2015; Atwood et al., 2013; Campbell et al., 2013; Wang et al., 2013; Xian et al., 2013; Ge et al., 2014). However, the complexity of MC meteorology continues to pose great challenges to quantitative characterization and prediction of $\mathrm{MC}$ atmospheric composition. Indeed, the region's high cloud cover prevents contiguous monitoring of aerosol particles (Reid et al., 2013). However, we have long known the response of clouds and precipitation to smoke particle loading to be strongly nonlinear (e.g., Reid et al., 1999; Feingold et al., 2001; Andreae et al., 2004; Lohman and Feichter, 2005).

The largest intensive operations period in the MC for 7SEAS occurred in 2012. Included was the deployment was a research cruise by the M/Y Vasco to study aerosol properties on the edge of the southwest monsoon (SWM) trough. Studied were "natural" particles as well as biomass burning and industrial emissions being transported from Indonesia, Malaysia, and Singapore into the eastern South China and Sulu seas. The Vasco previously supported 7SEAS in late September 2011 by performing a research cruise in the northern Palawan Archipelago $\left(\sim 11^{\circ} \mathrm{N}, 119^{\circ} \mathrm{E}\right)$ and sampling two major aerosol events originating from Borneo and Sumatra (Reid et al., 2015). This 2011 cruise was a trial for the more substantial 2012 effort described here, and it provided the means to conduct a detailed seasonal examination of how biomass burning emissions and life cycle related to Southeast Asian meteorology. Together, these two cruises provide the first ever, to our knowledge, measurements of aerosol properties in the remote SWM regions, increasing our understanding of their relation to regional meteorology and transport patterns.

Findings of the 2011 cruise were consistent with the conceptual analysis of MC aerosol life cycle in the monsoonal flow, as put forth by Reid et al. (2012), with supporting mesoscale simulations by Wang et al. (2013). In particular, the 2011 cruise highlighted the role of intraseasonal oscillations such as the MJO or boreal summer intraseasonal oscillation (BSISO) in regulating aerosol emissions and transport. While relationships between the MJO and aerosol loadings have long been hypothesized (e.g., Tian et al., 2008; Beegum et al., 2009; Reid et al., 2012), these research cruises provided direct verification of conceptual and numerical model simulations of what was occurring in environments under the clouds. The 2011 cruise showed that incorporated into the MJO signal was the associated TC cyclogenesis relationship put forth by Maloney and Hartman (2001). Reid et al. (2012) and Wang et al. (2013) suggested that this relationship strongly influences the development of aerosol events advecting into the South China and Sulu seas by way of monsoonal enhancements followed by large-scale subsidence associated with TC passage. Further, the 2011 Vasco cruise highlighted the importance of finer-scale features such as squall lines in regulating over-ocean wet deposition. Ultimately, a key finding of the 2011 cruise was that while monsoonal-scale flow patterns and convection are important, short-lived phenomena can strongly modulate cloud condensation nuclei (CCN) concentrations, resulting in significant perturbations to large-scale aerosol transport events that are difficult to account for in both observational and modeling studies. Demonstrated covariance of thermodynamic structure and aerosol properties in convective environments highlighted the need for any study of aerosol, cloud, and precip- 
itation interaction to control for meteorological confounding with aerosol properties to potential cloud and precipitation impacts.

This paper is the second of two examining the scale dependencies of regional aerosol meteorology for the 2012 SWM season. We rely on Part 1 (Reid et al., 2016) to provide an overview of the MC's 2012 biomass burning season. Here, focus is on the observations of the September 2012 research cruise as an indication of the aerosol behavior in the largely unobserved South China and Sulu Sea region. The description of the 2012 cruise contained in this paper continues the narrative that began in 2011. Cruise track, instrumentation, and other data are given. Results begin with a review of cruise relevant meteorology and aerosol transport. Observation results focus on the time series of Vasco measurements and their relation to the regional meteorology. Details on aerosol microphysics and chemistry will be provided in related papers - notably Atwood et al. (2016). In the final results section, we examine the nature of individual aerosol events, including from biomass burning and homogenous nucleation. We close with a discussion of the nature of aerosol meteorology found in the 2011 and 2012 cruises.

\section{Cruise instrumentation, track, and supporting data}

The 4-29 September 2012 research cruise was conducted on the same vessel with largely the same instrumentation and measurement configuration as the 2011 cruise (Reid et al., 2015). The vessel used was the Cosmix Underwater Research Ltd. M/Y Vasco, a 186 ton/35 m ship used for regional diving applications, including salvage, tourism, and research. However, the cruise was 12 days longer in duration and ventured further south, as far as Balabac Island on the southern tip of the Palawan Archipelago ( $\left.7.6^{\circ} \mathrm{N} ; 117.0^{\circ} \mathrm{E}\right)$, less than $100 \mathrm{~km}$ from the northern tip of Borneo (Fig. 1). Details on the Vasco and its instrumentation can be found in Reid et al. (2015), although a brief overview and notable changes from 2011 are described below. This is followed by descriptions of the cruise track and finally of the ancillary data used in this analysis.

\section{1 $\mathrm{M} / \mathrm{Y}$ Vasco instrumentation}

Instrumentation for 2012 was largely similar to 2011. A bow mast provided high-rate sampling at $50 \mathrm{~Hz}$ for turbulent fluxes using a Campbell CSAT3 3-D sonic anemometer and $\mathrm{LI}-\mathrm{COR} \mathrm{H}_{2} \mathrm{O} / \mathrm{CO}_{2}$ gas analyzer. An inertial measurement unit (IMU) consisting of a GPS, a gyro-stabilized electronic compass, and accelerometers was used to characterize the ship position and orientation for ship motion removal from the turbulence measurements. Mean meteorological measurements were made by an RM Young propeller anemometer, a Campbell ventilated temperature, and humidity probe and a barometer for static pressure. Dupli-

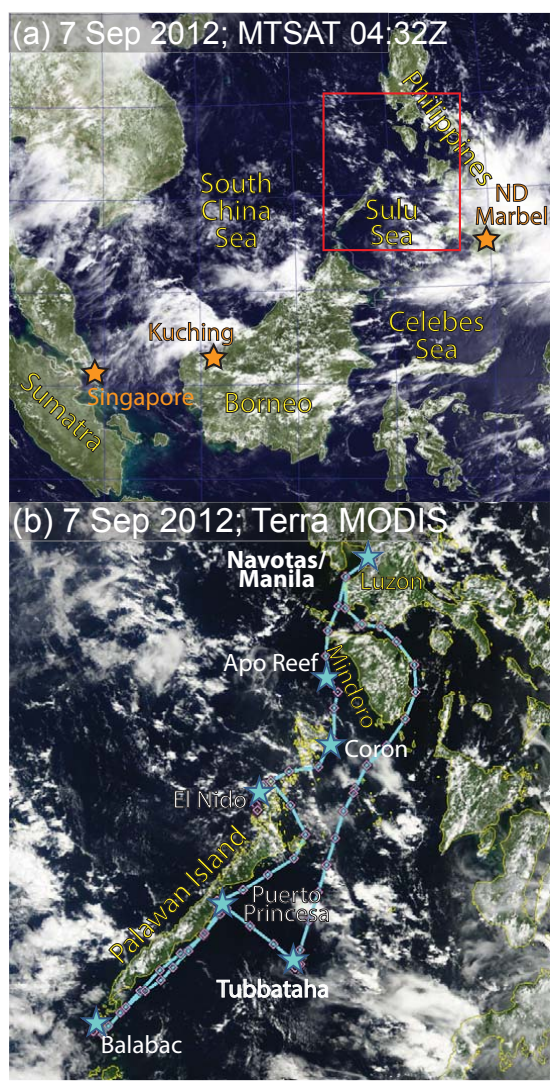

Figure 1. Overview of the study domain. (a) Regional MTSAT false color visible image of 7 September 2012 - the clearest day of the mission. AERONET sun photometer sites used in this analysis are also marked. (b) Cruise track with major sampling locations starred. Minor ticks during transits are $3 \mathrm{~h}$ apart.

cate measurements for mean meteorology and precipitation were made by a Vaisala Weather Transmitter WXT520 for quality assurance purposes. Differences between all sensors for temperature were within $0.3^{\circ} \mathrm{C}$, RH within $5 \%$, pressure within $0.5 \mathrm{hPa}$, and winds within $0.5 \mathrm{~m} \mathrm{~s}^{-1}$. Downwelling short- and long-wave radiation was measured by Kipp and Zonen CMP 22 and CGR4 instruments, respectively. Cloud cover was monitored with a Vaisala C31 ceilometer. InterMet 1-AB radiosondes were released two to three times a day when the ship was at a moorage. New to the 2012 cruise was an OTT Parsivel disdrometer to monitor rain rate and droplet size distribution.

Atmospheric composition measurements made on the bow also largely mimicked the 2011 cruise. PM $_{2.5}$ filters were collected by $5 \mathrm{~L} \mathrm{~min}^{-1}$ MiniVol Tactical Air Samplers (TAS) and analyzed by gravimetric, XRF, and ion chromatography at the Desert Research Institute. A second set of filters was analyzed for organic and black carbon by the thermaloptical method of Chow et al. (1993). The period of filter sampling ranged from 1 to 2.5 days, depending on estimated aerosol concentration. Size-resolved elemental data from $\mathrm{Na}$ 
through $\mathrm{Pb}$ were provided by XRF analysis at the Lawrence Berkeley Lab Advanced Light Source (ALS) on samples collected by an 8-stage Davis Rotating Uniform size-cut Monitor (DRUM) sampler (unheated $\mathrm{PM}_{10}$ inlet and cut points at 5, 2.5, 1.15, 0.75, 0.56, 0.34, 0.26, and 0.07 $\mu \mathrm{m}$; Cahill et al., 1985). Due to an electronics failure during ship installation, this instrument was manually rotated to provide data during specific periods. While total mass concentrations are still in analysis, we have high confidence in $\mathrm{PM}_{1}$ elemental ratios presented in this paper. As in Reid et al. (2015), sulfur, potassium, and vanadium ratios are used as markers to help separate industrial anthropogenic from biomass burning particles. For trace-gas analysis, 95 whole-air gas samples were collected for gas chromatography analysis by the University of California Irvine (see Colman et al., 2001, for a list of $60+$ compounds provided, details on analysis methods, and relative uncertainties). Of these, 85 passed internal quality assurance tests.

Aerosol microphysics instrumentation was located in a forward locker fed by a $3 \mathrm{~cm}$ diameter $/ 4 \mathrm{~m}$ long inlet. Wind directional data were used to ensure that only periods with air moving over the bow were used, in order to remove periods of contamination and self-sampling. Periods of residual self-sampling were also abundantly clear from $\mathrm{CN}$ and total particle counts. Like the previous cruise, a base set of aerosol scattering, absorption number and size was made and processed by two TSI three-wavelength $(450,550,700 \mathrm{~nm})$ nephelometers (Anderson et al., 1996) - one ambient and one hearted dry $(50 \% \mathrm{RH})$ - a Radiance Research threewavelength $(440,523,660 \mathrm{~nm})$ Particle Soot Aerosol Photometer (PSAP; Bond et al., 1999), TSI condensation nuclei counter (CPC), a combined DMT benchtop Passive Cavity Aerosol Sizing Spectrometer (PCASP), and a TSI Aerodynamic Particle Sizer (APS; Reid et al., 2006) for fine and coarse model particle sizing, respectively. A Maritime Aerosol Network (MAN) Microtops handheld sun photometer (Smirnov et al., 2011) was brought on board for measuring aerosol optical thickness (AOT) on those rare cloud-free occasions that permitted solar observation.

Significant additions were made to 2012 cruise relative to 2011 in regard to aerosol microphysics. First, data from previous campaigns showed that the lab-bench PCASP instrument was prone to calibration drift, and so a second PCASP configured in an aviation pod and heated inlet was placed on the Vasco top mast in a manner as described in Reid et al. (2006). This instrument proved to be much more reliable and steadfast in calibration and hence is used in this paper's analysis. Also supplementing particle size in 2012 was a combined electrostatic classifier/cloud condensation nucleation counter $(\mathrm{CCNc})$ package to measure the size-resolved $\mathrm{CCN}$ characteristics. This system and its analysis are described in detail in Atwood et al. (2016) but are summarized here. This system provided aerosol particle size distributions and hygroscopicities across a size range of 17$500 \mathrm{~nm}$ using a size-resolved CCN system similar to Petters et al. (2009). Coarse-mode particles were first removed using a URG cyclone with an approximate $1 \mu \mathrm{m}$ and $50 \%$ size cut before being dried using a Perma Pure poly tube Nafion column. Air was drawn through a TSI 3080 Electrostatic Classifier and model 3081 Long DMA column, measuring particles between 17 and $500 \mathrm{~nm}$ in diameter. Sampled air was then split between a TSI 3782 water CPC with a flow rate of $0.6 \mathrm{~L} \mathrm{~min}^{-1}$, and a DMT CCNc. Hygroscopicity was assessed with the kappa parameter (Petters and Kreidenweis, 2007) using three-parameter activated fraction fits similar to Rose et al. (2010).

Finally, in parallel with the PSAP, multi-spectral absorption was measured with the newly developed NOAA Continuous Light Absorption Aerosol Photometer (CLAP). The CLAP is a filter-based system of similar configuration to the PSAP although loaded with seven sequential filters, eliminating the need for frequent filter changes. Its design requirements were driven by the high sensitivity necessary to monitor aerosol absorption in more pristine conditions at Global Atmospheric Watch stations. Both laboratory and field comparisons between the CLAP and PSAP show that they agree to within $10 \%$ (Ogren, 2016). For the 2012 cruise, the CLAP was integrated with the dry nephelometer.

\section{$2.2 \mathrm{M} / \mathrm{Y}$ Vasco cruise track and sampling schedule}

The Vasco cruise track is superimposed on a MODIS Terra image in Fig. 1b. Like the previous cruise, the Vasco home ported from Navotas, Manila Bay, Philippines. Aerosol sampling was also performed in a manner similar to the 2011 cruise, conducted at a series of anchorages that were protected from the swell yet provided unobstructed sampling of the ocean. Typically these anchorages were behind reef zones or small islands that had little breaker activity or swell. Aerosol sampling was also conducted when the air was flowing within $\pm 50^{\circ}$ of the bow both while in transit and at moorage. Given the consistent nature of winds while at moorage, the Vasco naturally weather-vaned with the bow pointed into the wind.

The Vasco took on provisions once at Liminangcong $\left(11.0^{\circ} \mathrm{N}, 119.3^{\circ} \mathrm{E}\right)$, near the El Nido anchorage on 10 September, and twice at Puerto Princesa, Palawan Island $\left(9.7^{\circ} \mathrm{N}, 118.8^{\circ} \mathrm{E}\right)$, overnight on 13 and 19 September 2012. The Puerto Princesa port calls divided the cruise into thirds, which were distinct in geographic region and the sampled environment. In the first phase of the cruise (4-13 September), the Vasco sampled the same locations as the 2011 cruise. From Manila Bay, the Vasco transited to Apo Reef for a day of sampling $\left(12.7^{\circ} \mathrm{N}, 120.5^{\circ} \mathrm{E} ; 6\right.$ September), followed by a day at Coron Island $\left(11.9^{\circ} \mathrm{N}, 120.3^{\circ} \mathrm{E} ; 7\right.$ September $)$, and finally 4 days on station at El Nido behind the Guntao Island reef $\left(11.1^{\circ} \mathrm{N}, 199.2^{\circ} \mathrm{E}\right.$; 8-12 September). On 12 September, the Vasco transited the east side of Palawan Island to provision in Puerto Princesa overnight on 13 September. The Vasco headed south the morning of 14 September, starting 
the second phase of the cruise that brought the Vasco to the southern tip of the Palawan Archipelago on the western side of Balabac Island in the Balabac Great Reefs $\left(7.9^{\circ} \mathrm{N}\right.$, $116.9^{\circ} \mathrm{E}$; $15-19$ September), $100 \mathrm{~km}$ off of the northern tip of Borneo. This site provided excellent shelter while enabling unobstructed sampling of air from the southern South China Sea (SCS). Returning to Puerto Princesa on 19 September and departing on 20 September, the Vasco then entered its third phase of sampling: the middle of the Sulu Sea at Tubbataha Reef $\left(8.8^{\circ} \mathrm{N}, 199.9^{\circ} \mathrm{E}\right)$. The Vasco then returned to Navotas Manila Bay 26-29 September, but following winds prevented sampling.

\subsection{Ancillary model and satellite data}

Ancillary model and satellite data were utilized to provide a larger contextual understanding of the regional meteorological and aerosol environment. As described in Part 1 (Reid et al., 2016), for global-scale meteorology and aerosol monitoring we utilize the Navy Global Atmospheric Prediction System (NOGAPS; Hogan and Rosmond, 1991) and the offline Navy Aerosol Analysis and Prediction System (NAAPS) reanalysis (Lynch et al., 2016), respectively. In NAAPS four species are simulated: dust, biomass burning smoke, anthropogenic/biogenic fine (ABF), and sea salt. Here we focus entirely on fine-mode biomass burning and ABF species.

The Vasco data analysis was enhanced by using geostationary MTSAT satellite products (visible, IR, cloud heights, scatterometer, etc.) as found on the NEXSAT website (Miller et al., 2006; http://www.nrlmry.navy.mil/nexsat-bin/nexsat. cgi). To map regional precipitation, the Climate Prediction Center MORPHing precipitation product is used (CMORPH; Joyce et al., 2004). NASA MODIS Collection 6 level 3 data were also used (Levy et al., 2013). We also rely on key AErosol RObotic NETwork (AERONET) sites, located to monitor smoke exiting the MC (Holben et al., 1998; Reid et al., 2016). These included Singapore, indicative of smoke exiting Sumatra into the SCS; Kuching, Sarawak, indicating smoke departing western Borneo into the SCS; and Notre Dame of Marbel University (ND Marbel) on Mindanao, as an indicator of smoke transported into the Philippines via the Sulu and Celebes seas (Fig. 1). To monitor fine AOT, the Spectral Deconvolution Algorithm (SDA) product is used (O’Neill et al., 2003).

\section{Results I: relevant meteorological and aerosol environment}

An overview of the aerosol meteorology during the 2012 7SEAS campaign is provided in Part 1 (Reid et al., 2016) and thus not repeated in detail here. From a seasonal point of view, 2012 was a nominally "typical" biomass burning year for a slightly warm ENSO phase. There were low overall wind anomalies, and precipitation and fire activity were well within 1 standard deviation. However, regional AOTs were the second highest of the past several years, surpassed by the mammoth 2015 El Niño-induced fire season. While the averages are close to normal, the daily meteorology during the 2012 study period was quite variable, particularly during the research cruise. In the context of Vasco observations, we here discuss these relevant phenomena.

The most notable aspect of the 2012 cruise relative to its 2011 counterpart, and indeed all other 7SEAS regional studies, was the extreme variability in the monsoonal flows. This may in part be due to the MJO only weakly propagating across the MC during September in a fairly active convective phase (Reid et al., 2016). While at the seasonal mean level, wind patterns were near normal, with typical southwesterly winds and slight zonal enhancements aloft; during the entire month of September, daily flow patterns over the SCS changed measurably (Reid et al., 2016). These periods were largely defined by the migration of two tropical cyclones (TC $17 \mathrm{~W}$ Sanba and TC $18 \mathrm{~W}$ Jelawat), separated by easterly waves with significant flow reversals. The winds, precipitation, and boundary layer smoke patterns for the mission are exemplified in Fig. 2. Provided every 4 to 5 days through the cruise were NOGAPS winds at the surface $(10 \mathrm{~m}$; black) and $700 \mathrm{hPa}$ (magenta) overlaid on daily average CMORPH precipitation. Also shown are the midday MTSAT false color visible image and the corresponding NAAPS surface concentration of fine-mode particles (taken as a sum of biomass burning smoke and anthropogenic and biogenic fine species). For comparison, daily averaged AERONET $500 \mathrm{~nm}$ finemode AOTs for three sites surrounding the study region are presented in Fig. 3. These include Singapore, Kuching (Sarawak), and ND Marbel (Mindanao).

During the very first week at sea, monsoonal flow across the SCS was weak, associated with a westward-propagating wave consistent with the features of a tropical depression/easterly wave. On the day of Vasco's departure from Manila (4 September 2012), the Sulu Sea was already exhibiting anomalous southeasterly winds at the surface and nearly calm winds through the mid-troposphere. Winds shifted with the propagation of the wave, moving from southeasterly to westerly and northwesterly into the eastern part of the SCS, followed by full westerly and even northerly winds by the 7 th (Fig. 2). Northeasterly winds at $700 \mathrm{hPa}$ reached $10 \mathrm{~m} \mathrm{~s}^{-1}$. Thus for the first 5 days of the cruise at Apo Reef, Coron, and the first several days at El Nido, sampled air was largely not from the SCS but rather from the islands of Luzon, Mindoro, and Iloilo. NAAPS predicted likewise, with slightly above background fine-mode particle concentrations in the Vasco area dominated by the ABF species, originating locally. The reversal in monsoonal winds clearly kept smoke transport to the southern SCS. AOTs were nevertheless moderate at Singapore and Kuching early in the mission (above 0.5 ) as smoke advection was weak (Fig. 3). However, consequently AOTs at ND Marbel were at background levels, $\sim 0.1$. 


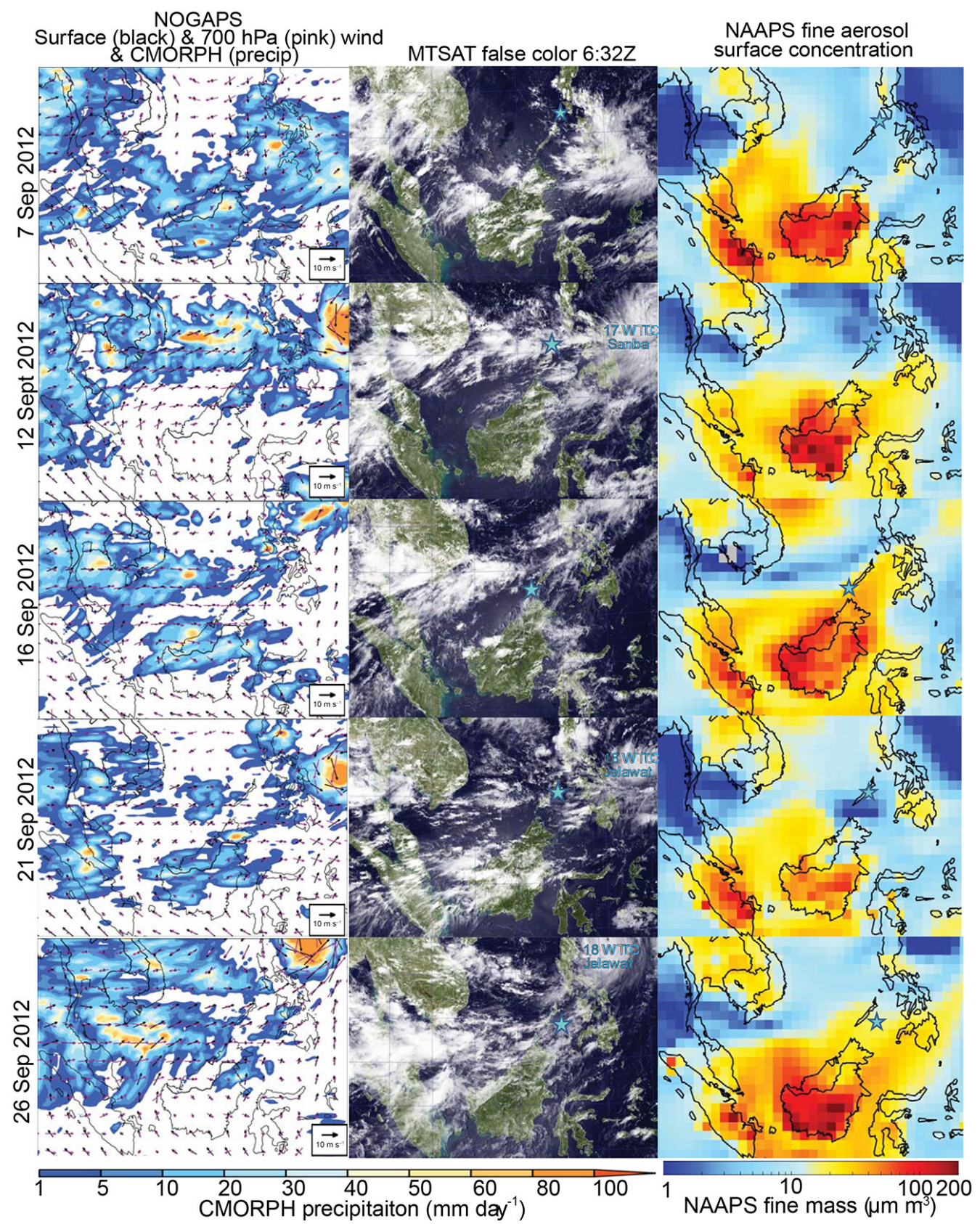

Figure 2. A matrix of NOGAPS wind (black indicates surface; pink is $700 \mathrm{hPa}$ ) and CMORPH precipitation, MTSAT visible false color imagery, and NAAPS surface fine-mode particle concentration (biomass burning plus anthropogenic and biogenic fine) for 5 representative days at major anchorages throughout the Vasco cruise. Selected dates are at major sampling moorings/anchorages: 7 September at Apo Reef; 12 September at El Nido; 16 September at Balabac Island; 21 September departing Puerto Princesa; and 24 September at Tubbataha Reef.

Monsoonal flow returned and precipitation began developing on 10 September 2012 while the Vasco was stationed in El Nido. This reestablishment of more characteristic flows occurred in association with the formation of what would become super-typhoon (STY) Sanba (TC 17 W) at Palau. By 12 September (Fig. 2), Sanba grew to typhoon strength, followed by rapid intensification to a super-typhoon the very next day. The slow northward migration of STY Sanba resulted in enhanced westerly components of the marine boundary layer and mid-tropospheric winds, as well as enhanced precipitation in a well-defined zonally aligned monsoonal enhancement/inflow arm. When the Vasco transited to Puerto Princesa on 12 and 13 September, the region was still under significant influence of TC Sanba. NAAPS predicted smoke remaining to the south due to enhanced zonal flow in the SCS and, indeed, significant ejection from eastern Bor- 


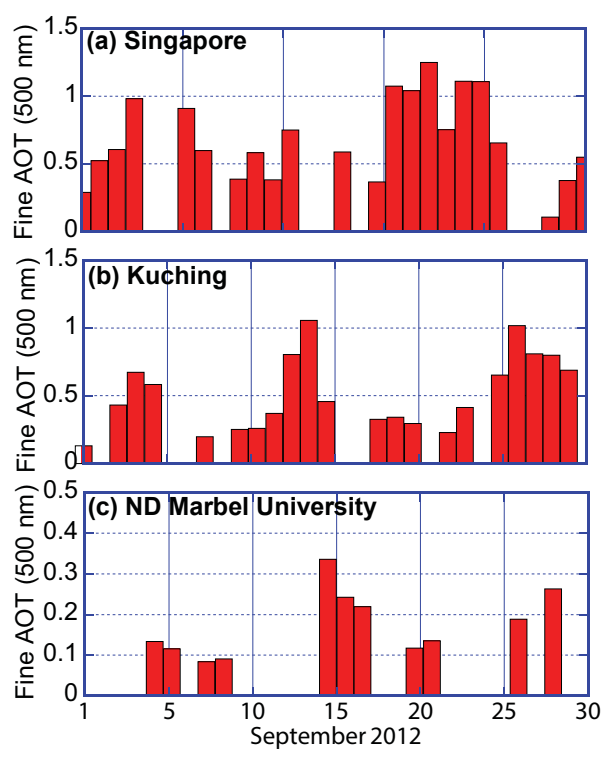

Figure 3. AERONET $500 \mathrm{~nm}$ fine-mode aerosol optical thickness for three sites surrounding the study area.

neo into the Celebes Sea south of the Vasco operating area occurred as predicted. Due to cloud cover, this ejection event was not visible in AERONET or MODIS data.

Upon departure from port on 14 September, heading for Balabac Island at the southern tip of the Palawan Archipelago, the slow-moving super-typhoon Sanba was still west of Luzon, with a well-defined monsoonal enhancement associated with the storm across the SCS. A massive smoke ejection event was modeled and observed coming out of Kuching into the SCS and was detected at ND Marbel a day later (Fig. 3). Likewise, smoke from eastern Borneo exited into the Celebes Sea. Even through 16 September, the influence of TC Sanba lingered as monsoonal enhancement extended from the Malay Peninsula through Luzon, with NAAPS suggesting smoke passing through the central Philippines.

For 17 through 21 September 2012, monsoonal winds slackened yet again, with westerly winds in the northern SCS and even some northerly components in the lower free troposphere. This is consistent with the propagation of a second easterly wave across the region and, like before, smoke and pollution were largely confined to the southern SCS. During this period, the Vasco transited back to Puerto Princesa (19 September), finally departing the morning of 21 September for its last station at Tubbataha Reef in the middle of the Sulu Sea. While on station there, monsoonal flow returned, with the formation of another super-typhoon, Jelawat (TC $18 \mathrm{~W}$ ). Jelawat had a similar life cycle to STY Sanba, forming over Palau and slowly migrating up the eastern side of the Philippines with a well-defined inflow enhancement across the SCS (e.g., 26 September). Also like STY Sanba, Jelawat intensified rapidly, becoming an intense super-typhoon, the strongest of the season. While surface winds had a typical southwesterly direction, winds in the free troposphere had significant northerly components across the SCS, unusual relative to the more typical westerly to southwesterly winds. Significant peaks in AOT were observed at Kuching and ND Marbel (Fig. 3). NAAPS suggested the Vasco at Tubbataha was influenced by two smoke plumes, a northern plume ejected from Kuching, and a southern plume exiting eastern Borneo. The Vasco then returned back to home port in Navotas, Manila (27-29 September), on the southern edge of the northward-propagating inflow of STY Jelawat.

\section{Results II: the time series of measurement on the Vasco}

Given the meteorological overview provided in Sect. 3, we can begin to interpret the aerosol and meteorological data from the cruise. Figure 4 provides the Vasco data timeseries of key meteorology, including $1 \mathrm{~min}$ (panel a) ventilated temperature, (panel b, c) RM Young wind, and (panel d) disdrometer-derived precipitation. Also shown are key aerosol and gas data during appropriate sampling conditions, the (panel e) CN concentrations, and (panel f) PCASPderived aerosol volume and whole-air gas can-sampled carbon monoxide (CO). Finally, the derived NAAPS fine-mode surface aerosol concentrations of biomass burning (gold) and anthropogenic fine (red) are also provided in panel g. Also overlaid was NAAPS $550 \mathrm{~nm}$ fine AOT.

Overall, there was significant variability in weather and aerosol parameters across the cruise. Winds ranged from becalmed in monsoonal breaks to sustained $12 \mathrm{~m} \mathrm{~s}^{-1}$ during monsoon enhancements, with peaks to $16-18 \mathrm{~m} \mathrm{~s}^{-1}$. Temperature, with a typical baseline of $28^{\circ} \mathrm{C}$, saw frequent drops of $2-4^{\circ} \mathrm{C}$ with corresponding spikes in wind speed $-\mathrm{a}$ telltale sign of cold pool passage (Reid et al., 2015). Roughly $\sim 25$ cold pool passages were observed. Peaks in temperature above $28^{\circ} \mathrm{C}$ baseline were rare, associated with cases of offshore flow from a nearby island while in transit. Precipitation occurred on all but 3 days, in short-lived but moderately intense rain showers $\left(\sim 1 \mathrm{~cm} \mathrm{~h}^{-1}\right)$. Particle concentrations also showed significant variability, with a baseline of $\sim 400$ $600 \mathrm{~cm}^{-1}$ in number and $1-2 \mu \mathrm{m}^{-3} \mathrm{~cm}^{-3}$ in volume (to get $\mu \mathrm{g} \mathrm{m}^{-3}$ estimated mass, multiply by assumed density, such as $1.4 \mathrm{~g} \mathrm{~cm}^{-3}$ as deemed appropriate with this dataset; e.g., $1 \mu \mathrm{m}^{-3} \mathrm{~cm}^{-3}$ is $\sim 1.4 \mu \mathrm{g} \mathrm{m}^{-3}$ ). CO, a key tracer for biomass burning, also showed significant variability, with a baseline of $\sim 70-80 \mathrm{ppbv}$, with multiple samples above $200 \mathrm{ppbv}$.

Variability in measured parameters is in line with the meteorology and aerosol environment discussed in Sect. 3. Early in the cruise, while under the influence of the strong monsoonal break (e.g., 4-9 September), winds were generally light and variable, precipitation infrequent, and particle mass concentrations low. NAAPS suggests the particles were largely anthropogenic and biogenic in origin with lit- 


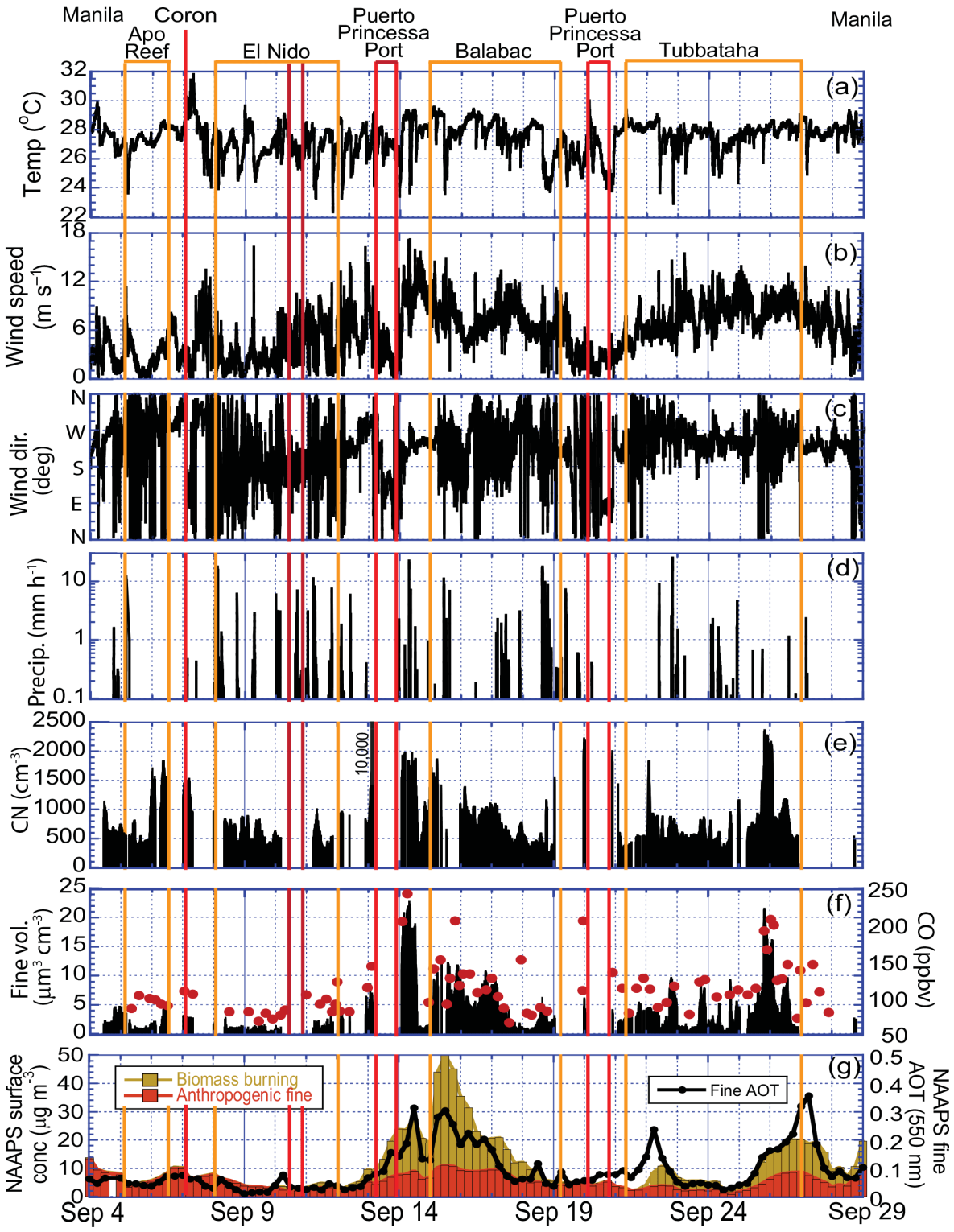

Figure 4. Time series of key meteorological and compositional data along the Vasco track (UTC). Locations of stationary sampling and in port periods are bound in orange and red brackets, respectively. Included are (a) temperature $\left({ }^{\circ} \mathrm{C}\right)$; (b) wind speed $\left(\mathrm{m} \mathrm{s}^{-1}\right)$; (c) wind direction; (d) precipitation rate $\left(\mathrm{mm} \mathrm{h}^{-1}\right)$; (e) condensation nuclei count $\left(\mathrm{cm}^{-3}\right)$; (f) fine-mode volume as derived by the PCASP $\left(\right.$ black $\left.\mu \mathrm{m}^{3} \mathrm{~cm}^{-3}\right)$ and the gas can CO (red dots, ppbv). Also shown is (g) Combined NAAPS model-derived fine-mode mass and AOT sampled along the Vasco track.

tle biomass burning influence. $\mathrm{CO}$ observations support this. We attribute one prolonged spike in $\mathrm{CN}$ on 6 September and another peak in number but not mass on 13 September 2012 to a nucleation event. These nucleation events are discussed in the next section.

When the SWM winds returned (as is evident in the ship time series, notably $\sim 10$ to 19 September 2012), particle concentrations increased, peaking in mass around 14-16 September, in agreement with the smoke event modeled in NAAPS (Fig. 2), although not necessarily in relative magnitude. Relaxation of the monsoon on 19 and 20 Septem- ber showed an associated decrease in particle concentration. After the second monsoon break when the Vasco left for Tubbataha Reef on 21 September, the monsoon flow returned, bringing pockets of polluted air with particle counts to $2000 \mathrm{~cm}^{-3}$ and CO to 200 ppbv. NAAPS simulated these pockets of air as a low-frequency signal and was largely unable to resolve fine-scale features.

With the overall time series of ship-measured meteorology and particle concentrations in agreement with the overall regional analysis, we can delve more deeply into particle and gas characteristics, presented in Fig. 5. Shown is 


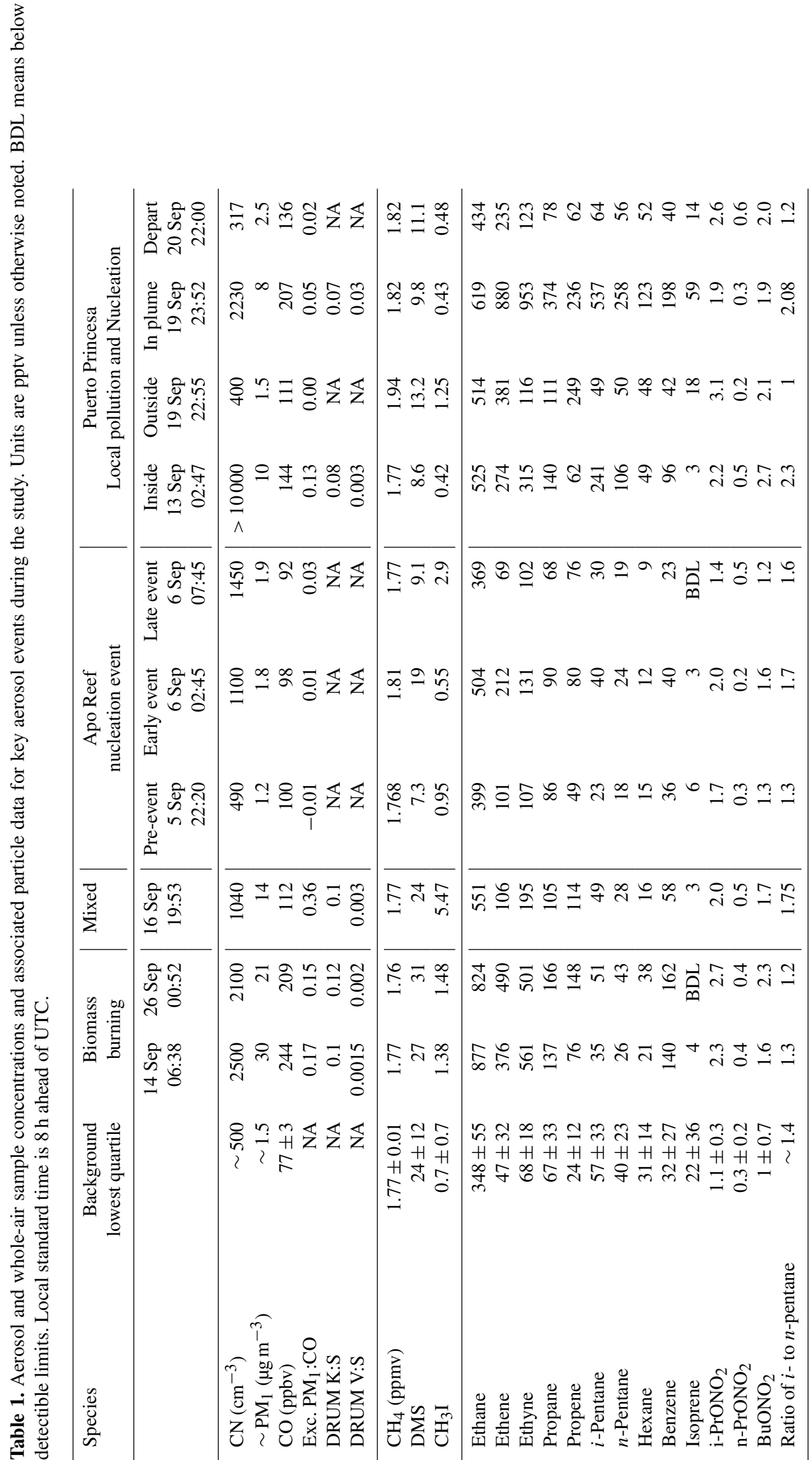



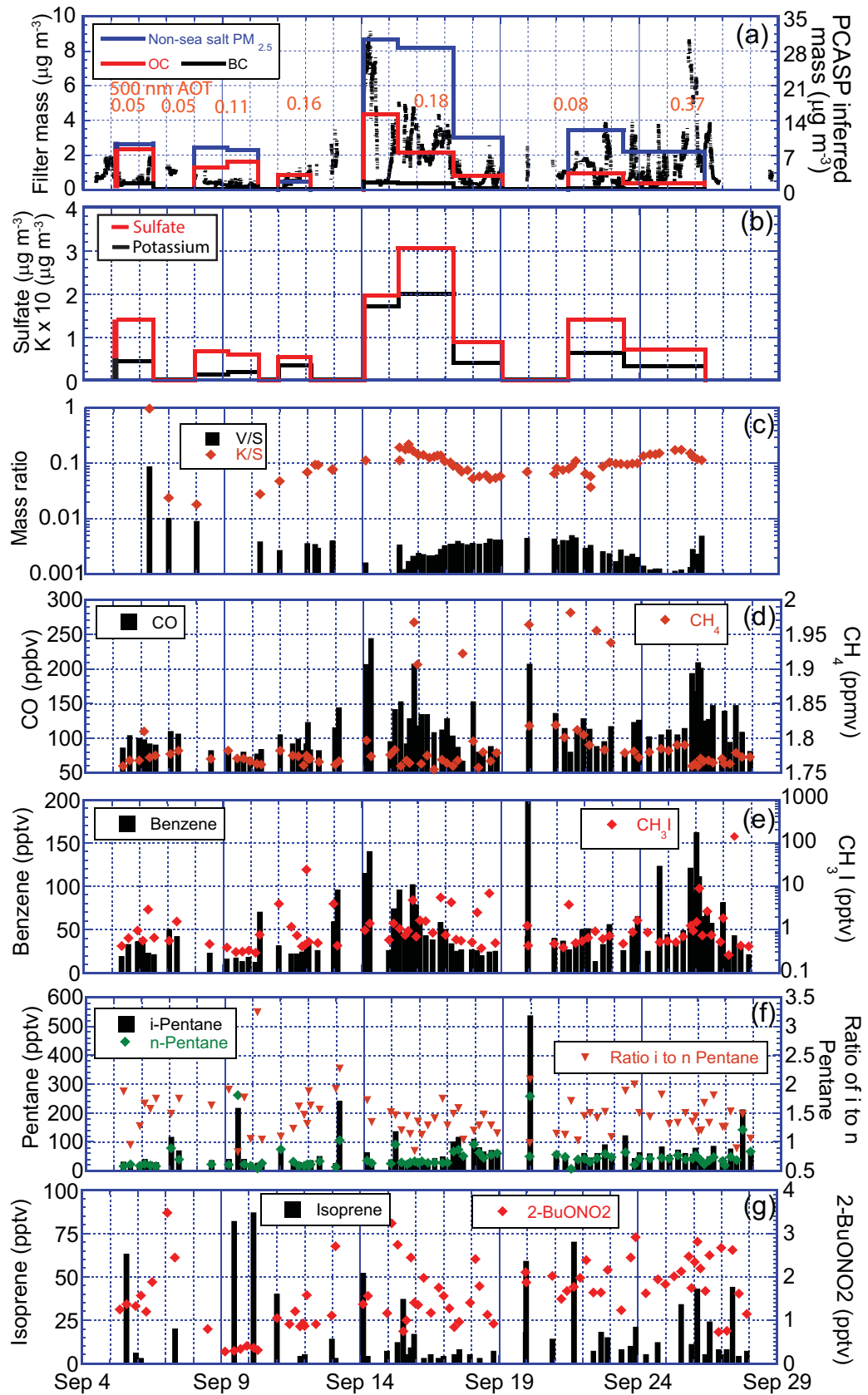

Figure 5. Time series of chemistry measurements including (a) filter-based gravimetry and organic carbon and black carbon. Also shown is 30 min averaged fine mass inferred from the PCASP, assuming a density of $1.35 \mathrm{~g} \mathrm{~cm}^{-3}$. Labeled are $500 \mathrm{~nm}$ AOT from the MAN Microtops sun photometer; (b) filter sulfate and potassium; (c) DRUM sampler elemental ratios of vanadium and potassium to sulfur; (d) wholeair sampled CO and methane; (e) whole-air sampled benzene and methyl iodide; (f) whole-air sampled $i$ - and $n$-pentane with their ratio; (g) whole-air sampled isoprene and 2-butyl alkyl nitrate.

(panel a) non-sea-salt $\mathrm{PM}_{2.5}$ gravimetry from filters, with corresponding quartz filter analyses of organic and black carbon. For comparison, an inferred 30 min PCASP-derived dry mass concentration using an assumed density of $1.4 \mathrm{~g} \mathrm{~cm}^{-3}$ is presented. This value of density provided good closure (unity slope; $r^{2}=0.8$ ) between the temporally integrated PCASP and gravimetric values and is close to the density for dry biomass burning of $1.35 \mathrm{~g} \mathrm{~cm}^{-3}$ as measured by Reid et al. (1998). Zero values of filter mass are associated with nosampling periods due to the relative wind direction over the bow. Shown in Fig. $5 \mathrm{~b}$ are the Teflon filter-derived $\mathrm{K}$ and $\mathrm{SO}_{4}$ values, followed by (panel c) elemental ratios of vanadium and potassium to sulfur from the DRUM sampler, used as an indicator to separate aerosol with industrial from biomass 
burning origins. Also provided in Fig. 5 are key whole-air gas sample species. While there are no unique chemical identifiers to isolate natural, biomass burning, and other anthropogenic sources, several species warrant attention. Included are (panel d) $\mathrm{CO}$ and $\mathrm{CH}_{4}$; (panel e) benzene and methyliodide as commonly used key indicators for biomass burning (Ferek et al., 1998; Akagi et al., 2011); (panel f) $i$ - and $n$-pentane as well as their ratios, with enhanced ratios suggesting more industrial rather than biomass burning sources (McGaughey et al., 2004; Simpson et al., 2014); and, finally, (panel g) isoprene and 2-BuONO, a photooxidation product of butane and indicator of photochemistry. Based on these data, we provide sample data for background and particularly interesting events in Table 1. These are discussed in Sect. 5.

"Baseline" particle characteristics in Table 1 are taken as the lowest quarter of measured concentrations. Particle number baseline concentrations in the marine boundary layer was $\sim 500 \mathrm{~cm}^{-3}$, with concentration rarely dropping much below that. Similarly, baseline fine-mode aerosol mass concentrations from filters and inferred from the PCASP were on the order of $1-2 \mu \mathrm{g} \mathrm{m}^{-3}$. Baseline CO was $\sim 77 \mathrm{ppbv}$. These values are somewhat larger than what was found in 2011, which had baseline particle number and mass concentrations of $150-350 \mathrm{~cm}^{-3}$ and $1 \mu \mathrm{g} \mathrm{m}^{-3}$. Part of this difference is 2012's closer proximity to Borneo source regions along the cruise track. Further, for periods when the Vasco was in the northern region, winds were anomalous and precipitation reduced due to the presence of easterly waves. Thus, there was more sampling of Philippines islands and regionally reduced wet scavenging. Interestingly, $\mathrm{CO}$ baseline values of $75 \mathrm{ppbv}$ were lower than the 2011 cruise of $\sim 90$ ppbv. This may be representative of wet scavenging of particles in 2011, with slight CO enhancements remaining.

Perturbing the aerosol baseline were many significant events with particle number and mass concentrations to $+2500 \mathrm{~cm}^{-3}$ and $20-30 \mu \mathrm{g} \mathrm{m}^{-3}$, respectively. Of particular note were aforementioned spikes in $\mathrm{CN}$ measured when the Vasco was moored at Apo Reef and Coron, in air masses moving offshore of the islands of Mindoro and Luzon. Also, spikes were observed entering port or in the vicinity of island cities, such as 13 and 20 September while the Vasco was downwind of Puerto Princesa. During one event (13 September 2012), high number ( $>10000 \mathrm{~cm}^{-3}$ ) but low mass concentration periods were observed consistent with a particle nucleation event. $\mathrm{CO}$ and volatile organic compounds (VOCs) also showed significant variability and enhancements (Fig. 5 and Table 1).

Observations of AOT from the Vasco were rare due to the high cloud cover associated with the SWM. Nevertheless, several observations of $500 \mathrm{~nm}$ AOT from the MANprovided Microtops handheld sun photometer were made throughout the cruise (labeled on Fig. 5a). Background conditions were just that, ranging from 0.05 to 0.11 - typical of remote oceans (Smirnov et al., 2011). Only two observations were available during significant aerosol events transported from the MC, however. These included a value of 0.18 in the second half of the first event on 16 September and a high of 0.37 for the peak of the second event on 25 September 2012.

In comparison to observations, the NAAPS model simulations of aerosol loadings near the Vasco exhibited mixed performance relative to the outstanding comparisons for 2011. For example, NAAPS did simulate some aspects of aerosol transport, such as the broader aspects of the 13-18 September 2012 period. However, the model had difficulty capturing the most significant pulses, such as observed spikes on 14 and 25 September. NAAPS also included other moderate events that did not materialize, such as 10-11 September and 24 and 29 September. The use of satellite precipitation to constrain scavenging processes in NAAPS improves representation of variability in aerosol loadings in high emission and high convection environments, although finer-scale features, unresolvable in a $1 \times 1^{\circ}$ transport model, are clearly important.

In regards to AOT, the NAAPS analysis performed exceedingly well. This is despite the fact that NAAPS had little data to assimilate in the Vasco region. Background NAAPS AOTs were on the order of $0.05-0.1$, equivalent to 0.07 to 1.2 if one predicts an AOT at $500 \mathrm{~nm}$. NAAPS also predicted the two Microtops AOT observations well, predicting 0.2 at $550 \mathrm{~nm}$ or 0.22 at $500 \mathrm{~nm}$ for the 16 September case measured at 0.18 , and 0.37 at $550 \mathrm{~nm}$ or 0.40 at $500 \mathrm{~nm}$ for 26 September measured at 0.38 .

Finally, from a photochemistry point of view, there were notable observations throughout the cruise track. For example, spikes in isoprene were frequently found in the vicinity of islands (Fig. 5g) but also occasionally a day's distance from shore. At concentrations near 100 pptv, these levels are rather low compare to terrestrial source regions, where values on the order of 1-5 ppbv are expected and measured (e.g., Wiedenmyer et al., 2005; Hu et al., 2015). However, spot cans on the interior of islands taken as part of the 2011 Vasco cruise did reach 1 ppbv (Reid et al., 2015). Similarly, 2- $\mathrm{BuONO}_{2}$, an indicator of photochemistry, also showed sporadic behavior, in this case associated with both smoke events and urban plumes alike. Finally we observed sporadic cases of strongly enhanced methane (to $1.95 \mathrm{ppmv}$ from a 1.77 ppmv baseline), which in general did not correlate with $\mathrm{CO}$ or any other species. This very easily could be indicative of gas-hydrate-derived methane production in under-ocean cold seeps in the SCS (Suess, 2014). While these observations are interesting, we leave their analysis to another paper.

\section{Results: aerosol meteorology of significant aerosol events}

From Sects. 3 and 4, the measured aerosol and meteorological environment during the 2012 cruise was found to be much more complex than the 2011 counterpart. The meteorology was more variable, and additional aerosol phenom- 

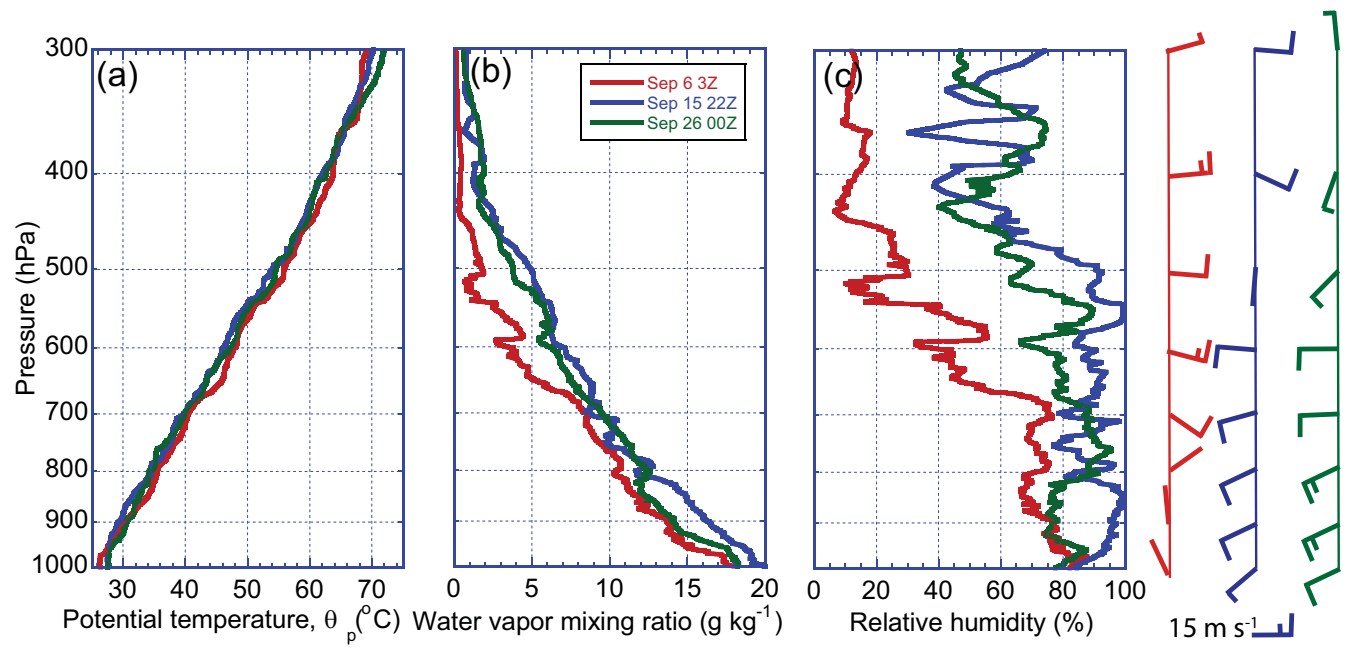

Figure 6. Sounding profiles of (a) potential temperature, (b) water vapor mixing ratio, and (c) relative humidity for profiles corresponding to the nucleation event on 6 September at Apo Reef and the biomass burning cases of 15 and 26 September at Balabac Island and Tubbataha Reef, respectively. Wind flags for these cases are marked on the far right.

ena, including from urban plumes and nucleation events, were sampled. Ultimately, the aerosol events were relatively short lived compared to 2011. Indeed, more prevalent highfrequency phenomena, such as particle concentration drops due to cold pool or the occasional spike in $\mathrm{CN}$, were observed (Fig. 4). In this section, we delve into more detail on the aerosol meteorology of key aerosol events. To help inter-compare aerosol events, particle concentrations and key whole-air can samples with associated aerosol particle concentrations are provided in Table 1. Thermodynamic data for soundings collected in three key events are given in Fig. 6. Atwood et al. (2016) go into much greater detail on the implications of these events to aerosol microphysics.

\subsection{Significant events transported from the Maritime Continent}

One can interpret the NAAPS data coupled with PCASPinferred mass, $\mathrm{CO}$ vs. $\mathrm{CH} 4$, elemental ratios, and gas ratios (notably the ratio of $i$-to- $n$-pentane) as indicative of two very clear biomass-burning-dominated event periods sampled on the Vasco: 14-17 and 25-27 September 2012. There are also multiple small aerosol and $\mathrm{CO}$ enhancements visible, especially late in the cruise. While we say these are biomass burning events, we must emphasize that it is likely that other species were transported with the open burning emissions, including urban and shipping fossil fuel emissions and biofuel. Regardless, the two major event periods have every indication of being dominated by open burning (including the smoke we could smell on the ship) and warrant special attention. Extracted from Figs. 3 and 4 are major gas species and ratios in Table 1. These include the peak values for biomass burning on 16 and 26 September, as well as a mixed biomass burning/anthropogenic pollution period on
16 September. The Vasco time series, radiosondes releases in Fig. 6, and particular samples in Table 1 are discussed in detail below.

\subsubsection{Puerto Princesa to Balabac sampling: the 14-17 September 2012 event}

Details of the 14-17 September event are provided in time series fashion in Fig. 7 for the Vasco departing Puerto Princesa through its Balabac anchorage and the start of its return home. To describe the lead up to the event, included in Fig. 7 are MTSAT visible satellite images for (panel a) 13 September and (panel b) 14 September at 04:32 UTC with the combined Terra and Aqua $550 \mathrm{~nm}$ AOT for that day. Also recall that wind, precipitation, and satellite imagery for the middle of the event are presented in Fig. 5c. Included in Fig. 7 is the Vasco time series of several key parameters, including (panel c) PCASP volume distributions, (panel d) temperature, (panel e) wind speed, and (panel f) precipitation. In terms of duration and fine particle and (based on Fig. 7) CO concentrations, the 14-16 September event was the most significant burning event sampled during the 2012 cruise (Table 1). Peak values for particle number and $\mathrm{CO}$ concentration reached as high as $2000 \mathrm{~cm}^{-3}$ and $250 \mathrm{ppbv}$, respectively, just as the Vasco moved south from Puerto Princesa and into the SWM flow. Whole-air sample data taken at this point give all of the key VOC markers of biomass-burning-dominated aerosol loading, including very high ethene and benzene. The ratio of $i$ - to $n$-pentane was $\sim 1.3$, also suggesting biomass burning over other anthropogenic emissions.

Based on the spike in AERONET AOT at Kuching and ND Marbel, Mindanao (Fig. 3), coupled with the satellite images of Fig. 7, this smoke event was part of a mass smoke ejection from Borneo starting on 12-13 September 2012 associ- 

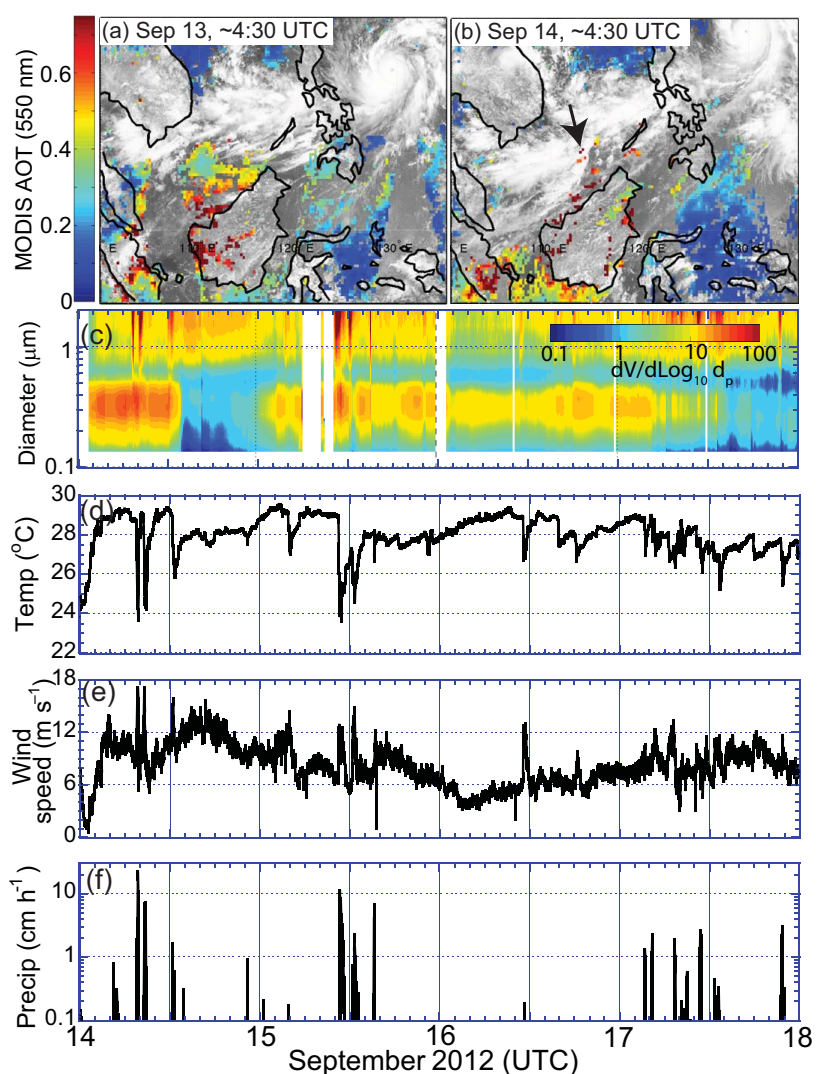

Figure 7. Satellite data and Vasco 1 min time series data describing the 14-17 September transport event. (a, b) Combined Terra and Aqua MODIS C6 $550 \mathrm{~nm}$ AOT overlaid on MTSAT visible channel for 13 and 14 September, respectively; (c) PCASP volume distribution; (d) temperature; (e) wind speed; (f) precipitation rate. The presence of a large squall line originating from a massive thunderstorm over the Malaya Peninsula that resulted in the 14 September 12:00 UTC clean period as evident in (c) is marked with an arrow in (b).

ated with the SWM enhancement from TC Sanba. Smoke extended through the Philippines into the Pacific Ocean (Fig. 2) with a fine-mode $500 \mathrm{~nm}$ AOT of 0.34 reported at ND Marbel, Mindanao, on 14 September. As discussed in detail in Atwood et al. (2016), particle size distributions were fairly constant, with a dry volume median diameter of $\sim 0.3 \mu \mathrm{m}$.

The transported smoke into the region was immediately noticed upon departure from Puerto Princesa $\sim$ 00:00 UTC on 14 September 2012, from both the data and a strong biomass burning smell. For the transit south to Balabac, weather was somewhat stormy, with moderate winds and periods of rain. However, the particle and $\mathrm{CO}$ concentrations continued to increase as the Vasco transited southward toward Balabac Island. At 12:00 UTC on 14 September, a very rapid drop in particle concentrations occurred while the Vasco was approaching the southern tip of Palawan Island (down to $500 \mathrm{~cm}^{-3}$ ), with partial particle and $\mathrm{CO}$ recovery when the Vasco made anchor at Balabac Island. There, higher particle concentrations remained for another 2 days with a slow decay to cleaner conditions of $500 \mathrm{~cm}^{-3}$, bringing the event to a close. On anchorage, isolated cells of precipitation were frequently observed in the vicinity. A final peak was observed and modeled in NAAPS as the Vasco departed for a return to Puerto Princesa near 23:00 UTC on 19 September.

The first radiosonde release occurred upon arrival at Balabac Anchorage on 15 September 2012 and showed generally moist conditions in the lower free troposphere (Fig. 6). However, air was dry in the upper troposphere and, based on our assessment, showed large-scale subsidence in association with TC Sanba. This dry air aloft may have inhibited some of the deep convection, thus allowing the transport event to persist.

The 14-17 September 2012 event has several interesting characteristics. First, while the NAAPS model generally predicted this event, the initial peak particle mass concentration was significantly underestimated. Second, the dramatic drop in particle concentration $\sim 12 \mathrm{~h}$ into the event would normally imply a cold pool. However, the particle decline occurred over a period of $45 \mathrm{~min}$, as opposed to the minute or two which one would expect from a cold pool event. While there was a temperature drop associated with the particle reduction, it was not as dramatic or rapid as other events. Indeed, there are several significant temperature drops in the hours during the high concentration period with only moderate perturbations to particle count. The NAAPS model did, however, have some reaction to the event and particle recovery. Clearly, this was not a typical cold pool as observed in the 2011 cruise (Reid et al., 2015).

We hypothesize that the dynamics of this particular event were based on two meteorological components coupled with an orography effect from Palawan Island. The first is related to coastal and orographic flows in western Borneo. The 1417 September 2012 event was initiated with the aforementioned outflow event on 12-13 September. Fine-mode AOTs at Kuching peaked at 1 on this date, while AOTs at Pontianak, further south, were constant at $\sim 1$. Throughout the mission, however, as seen in the model data in Fig. 5, the NOGAPS model had very low surface wind speeds right offshore of Kuching. In the lower free troposphere where winds are higher, they tended to be westerly, thus preventing smoke above the boundary layer from being advected offshore into the SCS. Thus in the model, the smoke does not get advected offshore very far, and it clings to the coast. However, based on MODIS AOT in Fig. 7a, we see that in fact the smoke was transported hundreds of kilometers offshore. This plume feature may also have had contributions from Sumatra. As hypothesized in Reid et al. (2012), and then demonstrated in mesoscale simulations by Wang et al. (2013), the sea/land breeze and orography play a significant role in modulating smoke transport on and off the islands of the MC. We hypothesize that orography and land breezes coupled with additional enhancement in monsoonal flows due to TC Sanba resulted in this significant ejection event. This phenomenol- 
ogy resulted in the significant smoke loadings at the Vasco as it left Puerto Princesa and was simultaneously underrepresented in the model. As the Vasco moved south, the model was able to account for the smoke that was transported closer to the Borneo coast.

The second significant feature of the 14-17 September 2012 event, the precipitous drop in smoke particle concentrations on 14 September at 12:30 UTC, was due to the remnant of a massive squall line, clearly visible in the Fig. 7b satellite image. Based on inspection of the MTSAT data, this was formed from a series of isolated cells aligned from south of the southern tip of Vietnam to the Malay Peninsula the night before. Cold pools from these cells were advected to the east as part of accelerated winds over the SCS in association with TC Sanba, eventually resulting in a squall line that was nearly $700 \mathrm{~km}$ long before daybreak on the 14 September. MTSAT imagery suggests the arrival of this squall line at Palawan Island at $\sim$ 12:00 UTC on 14 September, coincident with the drop in particle concentration. Palawan Island likely broke up this particular squall line and its associated cold pool, thus slowing the more typical rapid temperature and particle drop. We also suspect that the orography of Palawan Island had a role in the lack of particle perturbations in the cold pool events observed just after departure from Puerto Princesa around 08:00 UTC on 14 September.

In addition to modulation in particle concentration from the meteorology, aerosol and gas phase chemistry also showed significant variation during the event. To compare and contrast, within Table 1 are data from the peak of the event, sampled on 14 September, and another case 2 days later (labeled mixed). From the initial biomass burning onset through 16 September, all indications were that anthropogenic pollution could account for significant amounts of fine-mode aerosol mass. Noteworthy in Table 1 is that the ratio of excess $\mathrm{PM}_{1}$ to $\mathrm{CO}$ (based on the subtraction of the background level baseline) doubled between the early and late event periods. At the same time the $V$ to $S$ ratio, an indicator of industrial emissions, also doubled. Meanwhile the ratio of $K$ to $S$, an indicator of biomass burning, had clear and continuous variations starting at 0.1 , rising to 0.2 , and then falling back to 0.1 (Fig. 5). Also in Fig. 5 there is a remarkable decrease in OC mass fractions, dropping from $50 \%$ at the peak burning period (very typical of burning; Reid et al., 2005) to $25 \%$. The ratio of $i$ - to $n$-pentane increased from 1.3 to 1.75 for the two cases as well. All of these indicators are consistent with the hypothesis that significant amounts of anthropogenic pollution were also being advected with biomass burning compounds in ever-increasing quantities through the event. Indeed, based on filter data, sulfate alone could account for three-eighths of $\mathrm{PM}_{2.5}$ mass in the second half of the event.

\subsubsection{Puerto Princesa to Tubbataha sampling and the 25-26 September 2012 event}

The second biomass burning event occurred while the Vasco was moored at Tubbataha Reef. The Vasco departed from Puerto Princesa to Tubbataha Reef in the Sulu Sea on 21 September and ended its sampling with the return voyage back to Manila on 27 September. While there were sporadic peaks in particle and $\mathrm{CO}$ concentration on 23 and 24 September, the event was sampled for a $12 \mathrm{~h}$ period over 25-26 September. This event had peak particle concentrations and $\mathrm{CO}$ values nearly as high as the 14 September event but was considerably shorter in duration - nominally only $8 \mathrm{~h}$ long. There were also a number of minor events flanking either side of the primary event. NAAPS suggested a peak in smoke concentrations, although $12-18 \mathrm{~h}$ earlier than observed. NAAPS overpredicted smoke and pollution thereafter.

More detailed data from the 25-26 September 2012 period are presented in Fig. 8 in a manner similar to Fig. 7. Some aspects of the 25-26 September event mimic the earlier 14-16 September event. Particle size distributions, with a volume median diameter of $\sim 0.3 \mu \mathrm{m}$, were similar. Key VOC markers, as listed in Table 1, looked similar to the 14 September event. A TC (here Jelawat) was just east of the Philippines, with an extensive inflow arm reaching to southern Vietnam (e.g., 24 September meteorology and imagery in Fig. 5d). A day later, as TC Jelawat migrated northward, a large aerosol ejection event occurred along northwestern Borneo into the SCS, again visible in the AERONET time series (Fig. 3). Large-scale convection was suppressed from upper-tropospheric subsidence on the backside of the TC (Fig. 6). At the same time, NAAPS and MODIS AOT data suggest that for this case a large event also departed Sumatra, which we speculate may have been part of the sampled air mass of the principal event or perhaps of the secondary event that appeared 12:00 UTC on 26 September. Regardless, neither the modeling nor the remote sensing data provide enough information to make this attribution. As in the previous 14-16 September event, the TC's continued northward migration ended the event. Soundings were similar between the two events: relatively moist in the lower troposphere, with some drying aloft.

The comparison of the weather and PCASP time series for this event does show some interesting features. The most significant increase in particle concentration at 18:00 UTC on 25 September was heralded by a cold pool, with nearinstantaneous temperature drop and increased wind speeds. Generally, we think of cold pools being associated with convectively washed-out air or, as in the early period case (14 September), as having little effect on particle concentrations. However, in this case, particle concentrations increased, though the magnitudes of the temperature, wind, and precipitation perturbations were quite small. Thus, the event 

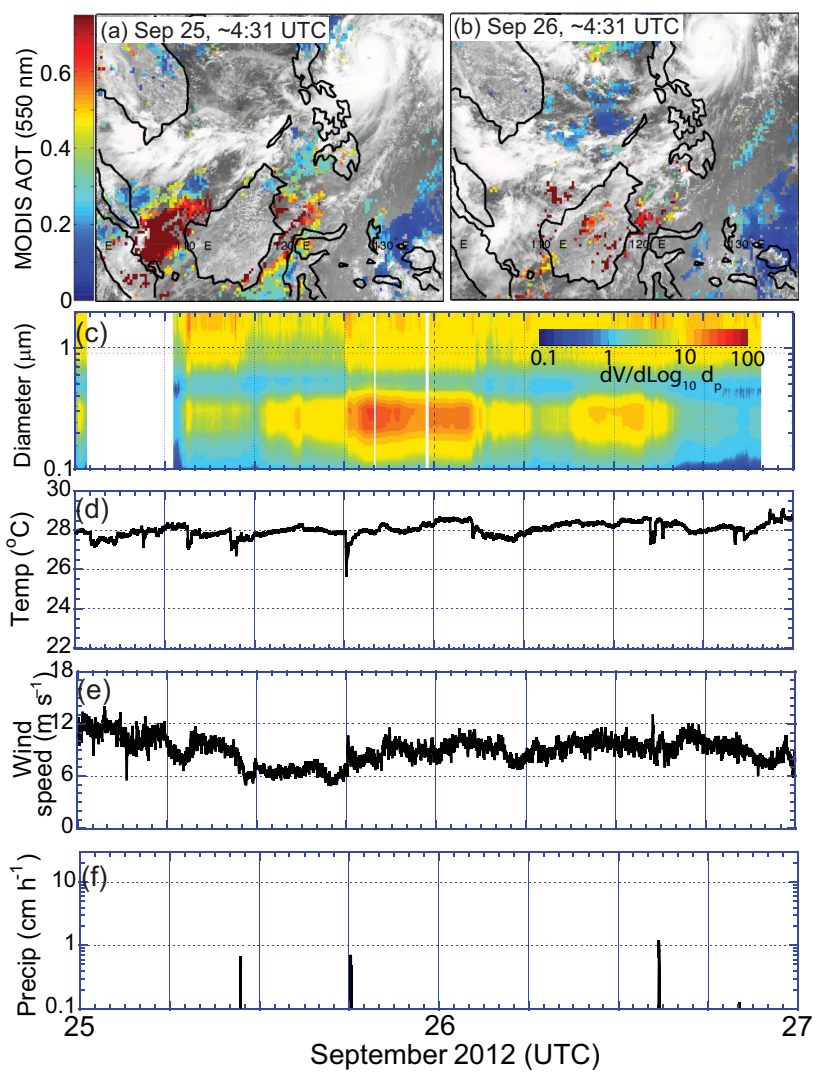

Figure 8. Same as Fig. 7 but for the 25-26 September 2012 smoke event.

may have been associated with some minor convection along the leading edge of the air mass.

\subsection{Local aerosol events}

While the primary focus of the 2012 Vasco cruise was to observe the nature of long-range biomass burning and anthropogenic aerosol transport from Borneo and Sumatra to the Philippines, we were mindful of the potential impact of local aerosol sources and nucleation. Indeed, there is significant diversity in model nucleation rates in the region (Yu et al., 2010) and virtually no observations. During the cruise, two significant types of local sources were observed: a nucleation event at Apo Reef on 5-6 September and a series of urban plumes as the Vasco neared the vicinity of port towns such as Coron and Puerto Princesa. These events are discussed in more detail below.

\subsubsection{Apo Reef nucleation event}

The first anchorage reached after departing Manila was at Apo Reef in the middle of the Mindoro Strait, on 5 and 6 September 2012. As noted in Sects. 3 and 4, during this period the SCS was experiencing a strong break in the SWM. The atmosphere was relatively dry above $700 \mathrm{hPa}$ (Fig. 6),

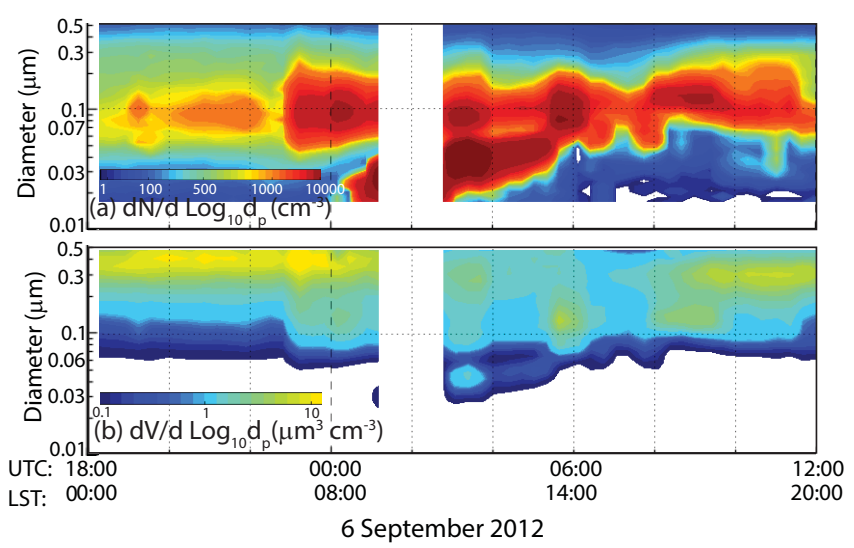

Figure 9. Electrostatic classifier particle number and volume distribution for the 6 September nucleation event at Apo Reef. Corresponding whole-air samples are listed in Table 1 including 22:20 UTC 5 September as a pre-event can, 02:45 UTC 6 September in the middle of the event, and 07:30 UTC 6 September for postevent.

with only scattered cumulus and congestus in the region. Boundary layer and lower free-tropospheric winds were generally northwesterly to easterly in the northern Philippines on these days, instead of the much more typical SWM flow. Consequently, sampled air masses on the Vasco were downwind from Luzon and/or Mindoro. On 6 September at $\sim$ 01:00 UTC ( $\sim$ 09:00 LST) the Vasco sampled a significant spike in $\mathrm{CN}$, in excess of $1500 \mathrm{~cm}^{-3}$. At the same time, filter and PCASP-inferred particle mass concentrations were low, only perhaps $1-3 \mu \mathrm{g} \mathrm{m}^{-3}$, and $\mathrm{CO}$ was only slightly above background at $\sim 100-110$ ppbv. During this early period in the cruise, the electrostatic classifier was still operational and resolved the aerosol particle size dynamics from 0.02 to $0.5 \mu \mathrm{m}$ (Fig. 7). Three whole-air samples were also collected during the event, including 22:20 UTC on 5 September as a pre-event can, 02:45 UTC on 6 September in the middle of the event, and 07:30 UTC on 6 September as a post-event sample (Table 1).

The aerosol dynamics for Apo Reef show the characteristics of a classic nucleation event (e.g., see review by Kulmala et al., 2004). Leading up to the event, particle concentrations were at $\sim 500 \mathrm{~cm}^{-3}$, with an estimated mass concentration $\sim 1 \mu \mathrm{g} \mathrm{m}^{-3}$. The fine-mode particle number distribution was fixed to a count median diameter (CMD) of $0.1 \mu \mathrm{m}$, but with significant enhancements throughout the event. Clearly, an air mass change occurred at $\sim 23: 00$ UTC 5 September, with an increase in particle concentration to $1000 \mathrm{~cm}^{-3}$ and a slight fine-mode particle volume increase to $\sim 1.5 \mu \mathrm{g} \mathrm{m}^{-3}$. Nucleation was indicated 09:00 local time, as solar radiation was increasing throughout the morning. Total concentration peaked at $1800 \mathrm{~cm}^{-3}$. The CMD of the ultrafine mode initialized at $0.02 \mu \mathrm{m}$, growing to $0.05 \mu \mathrm{m}$ in $5 \mathrm{~h}$. By 06:00 UTC (14:00 LST), the bimodal nature of the finemode aerosol population ended, with a strong $0.1 \mu \mathrm{m}$ number 
mode in place. The fine mass concentration was estimated to be $\sim 3-5 \mu \mathrm{g} \mathrm{m}^{-3}$ throughout the core of the event. While the ultrafine mode may have grown into this fine mode, there were additional modal shifts to $0.08 \mu \mathrm{m}$ over the next $2 \mathrm{~h}$, which may actually be more representative of the air mass. Also noteworthy is that at $\sim$ 03:00 UTC a simultaneous enhancement in both the fine and ultrafine mode occurred, suggesting a covariance in both the fine-mode particles and the nucleation event precursor gases. Indeed, this is consistent as the nucleation event occurred along with a strong increase in fine particle concentration.

While a separate paper will be devoted to the whole-air samples from the 2011 and 2012 cruises, it is noteworthy here that the VOC profile during the event is consistent with the nucleation event, coinciding with reactive anthropogenic gas emissions (Table 1). There were enhancements in reactive alkenes: roughly a factor of 2 enhancements in ethene and propene. There was also a factor of 2.5 increases in dimethyl sulfide over background and a slight increase in $\mathrm{CH}_{4}, i$-pentane, and $i-\mathrm{PrONO}_{2}$. All other species were relatively constant. Interesting, isoprene was near-detectable limits, as was pinene, suggesting that terrestrial biogenic influences had been photochemically removed upwind. Also missing are enhancements in biomass burning markers. $\mathrm{CO}$ was fairly constant at $95-100$ ppbv, as was benzene. Further the ratio of $i$ - to $n$-pentane increased from 1.3 to 1.7. All of this data points to the likelihood that the nucleation precursors were anthropogenic in origin from Luzon and/or Mindanao.

\subsubsection{Puerto Princesa plumes}

A second class of observed local aerosol phenomena occurred in association with urban plumes. While the Vasco cruise track was designed away from population centers, there were times during transit that their influence were considerable. These ranged from small boat emissions around coastal villages to observation of the urban plume of Puerto Princesa as the Vasco entered and exited the port to take on supplies. Focusing on Puerto Princesa, the Vasco visited on 13 and 20 September 2012, leading to four sets of observations. On three occasions, significant enhancement in particles due to the Puerto Princesa plume were clearly observed (for the exit on 14 September, the aerosol environment was dominated by the smoke event).

As the Vasco was nearing Puerto Princesa on 13 September, 02:00 UTC ( 10:00 LST), at approximately $30 \mathrm{~km}$ out, $\mathrm{CN}$ concentrations rapidly increased to instrument saturation at $10000 \mathrm{~cm}^{-3}$. At this point, the crew immediately suspected self-sampling and quickly shut instrumentation down. However, it was then realized that the wind was in fact traveling directly over the bow. Some of the instrumentation was then restarted, and a whole-air sample was collected. While the boundary layer was clearly biomass burning dominated upon departure the following day, the crew prepared to sam- ple the plume on the next visit, 19-20 September, for which cases concentrations peaked at only $\sim 2200 \mathrm{~cm}^{-3}$.

The pair of visits, while relatively isolated samples, nevertheless provides some insight into the nature of particle populations within the Philippine Islands. Key particle and gas measurements are included in Table 1 and can be compared to the Apo Reef and biomass burning events. Most importantly, the very high particle concentrations for arrival on 13 September have every indication of being a nucleation event. Unfortunately, as the electrostatic classifier was inoperative for this portion of the cruise, we cannot directly compare size distributions with the Apo Reef case. But comparison of PCASP and CN count showed a substantial aerosol population with diameters less than $0.1 \mu \mathrm{m}$. Winds were clearly in an outflow region for the city, and solar radiation was fairly intense in the late morning under only moderately cloud-free skies. On the visit on 19 September, a sample was taken just before arrival, and a subsequent sample was collected as the Vasco entered the harbor. Clear enhancements in $\mathrm{CN}$ were observed. Although, as reported by Atwood et al. (2016), there was no nucleation mode in this case, suggesting these particles were primary, this is not unexpected given the earlier time of arrival ( 08:00 LST) and full cloud cover. Similarly, upon departure in the $21 \mathrm{st}$, at 06:00 LST, particle concentrations were low $\left(<400 \mathrm{~cm}^{-3}\right)$, possibly partly as this was even before the morning commute.

Whole-air sample data for these cases provide us with other useful information. First and most notably, the use of the ratio of $i$ - to $n$-pentane in previous studies seemed to be justified, with values above 2 being clearly associated with the urban plume, and also slightly enhanced in the Apo Reef plume. Also hexane, a gasoline derivative, also appears to be a strong signature for Puerto Princesa. But in general for most species, the differentiation between "urban" and "biomass burning" in older plumes is not so straightforward.

\section{Discussion: comparison of the 2011 and 2012 studies}

This paper had two primary objectives: first, to provide a broad overview of the 2012 Vasco cruise, including instruments carried, cruise track, and the general characteristics of the regional environment sampled. Second, we wished to utilize the 2012 Vasco as a vehicle for continuing the narrative put forth in the 2011 effort on the nature of aerosol populations associated with the SWM. To our knowledge, these cruises provide the first published aerosol field measurements in the boreal summertime South China Sea and Sulu Sea regions.

The similarities and contrasts between the 2011 and 2012 cruise observations portray key aspects of the SWM aerosol system, pointing to a number of observational and prediction challenges. Certainly from an inter-seasonal, seasonal, and even monthly time period, the conceptual models of aerosol life cycle in the SWM by Reid et al. (2012) largely hold. 
Within the season, the MJO, in part, regulates large-scale precipitation patterns, which then affect aerosol event timing. TCs develop well-defined areas of monsoonal enhancement/inflow arms with accelerated surface winds that help draw smoke further into the monsoonal flow but may also lead to enhanced scavenging. Subsidence after TC passage, however, reduces convection, allowing for the smoke to be transported great distances in the monsoonal enhancements. At the same time, major land/sea breeze events can lead to significant aerosol ejections off-island. Ultimately, multi-day events are possible, such as the two events for 2011 and the 14-17 September event for 2012. Finally, while nearly "pure" biomass burning events are possible, there is more typically a mixture of biomass burning and other anthropogenic emissions. Both the comparison of the seasonal behavior and the measurements on the cruises bear these similarities out.

Several key differences between long-range transport characteristics in 2011 and 2012 are highly noteworthy. First, while the monsoon frequently has weak and strong phases, the 2012 case clearly showed how strong the effect of tropical waves moving through the region can be on low-level flow patterns. Indeed, the first week of the 2012 cruise coincided with uncommonly clear skies and even northerly winds. Such clear periods provide some of the rare opportunities for satellite observations. However, from a climatological point of view, this clear-sky bias fundamentally represents a skewed portrait of the aerosol system (Reid et al., 2013).

A second significant difference between 2011 and 2012 is that in 2012 biomass bringing events showed higherfrequency characteristics. This is likely in part due to the closer proximity of the Vasco to Borneo, where we speculate that a more significant role of convection along the coast of Borneo led to more pockets of smoke. Further, in 2012, the Vasco did not experience a regional clear day, as was caused by a TC propagating across Luzon and into the SCS at the end of the 2011 cruise. This leads to suspicion that many pockets of polluted air may be migrating through the region on a regular basis, obscured from satellite detection. Given the remote expanse of the region, such phenomenon can probably only be surveyed by aircraft.

High-frequency events in 2012 also included observation of two nucleation events and urban plumes. While it is often thought that these types of nucleation events only occur in the presence of gas precursors when there are few aerosol particles (e.g., Mäkelä et al., 1997; Kulmala et al., 2004; Boy et al., 2008), for the tropics and subtropics, nucleation events have also been noted in polluted urban environments (e.g., Cheung et al., 2011; Betha et al., 2013; Kanawade et al., 2014; Brines et al., 2015) and even in dense tropical smoke plumes (Reid et al., 2005). The Vasco observed both kinds. The Apo Reef nucleation event seemed to follow the more traditional relationship, starting with precursor gases in the presence of low aerosol particle surface area. Indeed, while in clean midlatitude marine conditions, Covert et al. (1992) observed explosive nucleation events and discounted local or transported sources. Instead, they suggested such an event was a natural outcome for a marine boundary layer with low particle surface area. It was later argued that nucleation in some remote subtropical to midlatitude areas is assisted by ion-mediated nucleation events formed by the ionization of molecules by cosmic rays (Yu et al., 2008). While Yu et al. (2008) considered such nucleation generally unfavorable in tropical regimes, they did predict significant nucleation on the periphery - notably west of the northern Philippines, south of Java, and east of New Guinea. Indeed, Yu et al. (2008) placed a nucleation hotspot right at our point of observation. Aided by anomalously clear skies, and thus high photolysis rates, we see this nucleation mechanism as being a reasonable contributor to the event. Indeed, it was the only such observed event in the two Vasco cruises.

The second type of nucleation event, in the outflow of a polluted urban plume, was observed by the Vasco outside of Puerto Princesa. Nucleation events with concentrations this high have been reported in urban tropical air in late morning (e.g., Cheung et al., 2011; Betha et al., 2013; Kanawade et al., 2014; Brines et al., 2015). Ultimately, whether in clean or more polluted conditions, aerosol nucleation events are probably not uncommon in the MC.

In addition to nucleation events, the Vasco in 2012 intersected many small plumes, as well as the strong urban plume of Puerto Princesa (population of $\sim 250000$ ). These observations remind us that while many of the islands of the MC are thought of as "remote" and outside of the megacities, they can nevertheless harbor reasonably sized populations. Given the significant use of biofuel or highly polluted engines, these islands can clearly emit significant amounts of CCN.

Finally, and perhaps most interestingly, the 2012 cruise demonstrated a new relationship between aerosol events, convective cells, and more organized squall lines. In 2011, drops in particle concentration were coincident with temperature, consistent with the notion that cold pool air was advecting into the region with aerosol particles already deposited out. From the wind shear and variable wind speeds shown in the profiles, the steering winds of the squall lines roll over polluted air masses underneath. Thus, these squall lines may be likened to "lawn mowers", ingesting or scavenging aerosol particles as they propagate.

Based on the work of Seigel and van den Heever (2012), which showed that dust generated ahead of cold pools on the leading edge of thunderstorms is lifted to mid-levels where the potential impact of aerosol particles as $\mathrm{CCN}$ was minimal, the 2011 cruise suggested that the nature of convection in the region often insulated itself from potential aerosol impacts. Certainly, the Vasco observed some of this behavior in 2012, but it also observed the opposite: cases where the telltale cold pool signs of rapid temperature drop and spikes in wind heralded the coming of a polluted air mass. Indeed, during the 14-18 September period in Fig. 7, both clear air and polluted air followed cold pools. While the wiring diagram 
for larger-scale features is largely well known and to some extent can be qualitatively captured by a coarse-grid model such as NAAPS, run with additional constraint from satellite precipitation products, there remains much to understand about aerosol life cycle in the vicinity of convective cells and squall lines. We suspect that a clue to the behavior when air pollution follows a cold pool event lies in the rather shallow temperature drops $\left(1-2{ }^{\circ} \mathrm{C}\right.$ vs. $\left.5-6^{\circ} \mathrm{C}\right)$. This may be an indicator that the convection is not so strong or that it may in part be a remnant. Such events may also be related to the nature of the initial formation of convection or a squall line relative to a polluted air mass. The origin of the convection, whether from a coastal ejection event or a large convective system, may play a role. Otherwise, steering winds and wind shear may be such that some moisture convergence occurs on the leading edge of an ejection event, leading to weak convection along the boundary. However, this situation thus far has not been observable from satellite.

To speculate, these events of thick aerosol plumes behind convection seem to be consistent with a land breeze origin, propagated much further than normal by the monsoonal flows. Certainly the temperature change and high aerosol loading behind a cloud top front matches aircraft observations of large land breeze ejection events in the Arabian Gulf (e.g., Reid et al., 2008). In the MC case, cloud development along land breeze fronts is much larger, leading to significant convection offshore of islands (e.g., Liberti et al., 2001; Qian, 2008; Virts et al., 2013).

Ultimately, 7SEAS and the Vasco cruises demonstrate that the arsenal of tools, in situ measurements, remote sensing, and models clearly have difficulty mapping contiguous aerosol fields and properties. Indeed, core aerosol science goals for the NASA Aerosol/Clouds/Ecosystems (ACE) mission focus on the use of remote sensing to constrain aerosol life cycle and cloud impacts. The transition of polluted to pristine aerosol environments is a significant science issue. The Vasco cruises point to the real world challenges posed to scientists studying aerosol-cloud interaction and challenge us to understand the many scale dependences inherent in the system, ranging from ENSO to the micro-meteorology and physics around clouds.

\section{Conclusions}

This paper provides an overview of the meteorological and aerosol environment measured by the M/Y Vasco, which sampled MC air in September 2012 along the entire length of the Palawan Archipelago, Philippines. This cruise was a longer follow-on to a similar research cruise the previous year (Reid et al., 2015) and was a significant component of the 2012 7SEAS SWM intensive period - a high water mark for observations throughout the MC. The Palawan region for this research cruise was selected for being a receptor of smoke and anthropogenic emissions from Borneo, Suma- tra, and the Malay Peninsula as emissions were advected by SWM flow into the seasonal monsoonal trough east of the Philippines. The key conclusions of this study are as follows.

The 2012 cruise home ported at Manila, Philippines, and sampled three major regions: (a) the upper Palawan chain and El Nido for 4-13 September 2012; (b) the southern Palawan chain and Balabac Island on the southern tip of the Palawan chain, $\sim 100 \mathrm{~km}$ north of the northern tip of Borneo, on 1419 September; and (c) the Sulu Sea and Tubbataha Reef on 21-29 September 2012. In the northern locations, the atmosphere was under the influence of an easterly wave, bringing unseasonable north-to-northeasterly winds and air from the northern Philippine islands of Luzon and Mindoro. Observations included a pronounced particle nucleation event in relatively clean conditions in a region where ion mediated nucleation was predicted by Yu et al. (2008). In the southern and Sulu Sea locations, biomass burning and anthropogenically polluted air masses were sampled, largely modulated by enhancement in monsoonal flows associated with two Category 5 TCs. Fine particle concentrations reached $\sim 35 \mu \mathrm{g} \mathrm{m}^{-3}$, and $\mathrm{CO}$ was as high as $250 \mathrm{ppbv}$. Finally, while transiting through Puerto Princesa for supplies, the city plume was also sampled, including a nucleation event in more polluted conditions with $\mathrm{CN}$ concentrations of $10000 \mathrm{~cm}^{-3}$. In comparison, "background" values of aerosol particle concentrations were on the order of $500 \mathrm{~cm}^{-3}$, roughly $50-100 \%$ higher than the cleaner background conditions sampled by the 2011 cruise.

The large-scale relationships between aerosol emissions, aerosol transport, and regional meteorology during the cruise broadly matched the conceptual models of Reid et al. (2012) regarding relationships to the MJO and TCs. However, easterly waves resulted in significant weakening of the monsoonal flow, and two slow-moving TCs located southeast of the Philippines resulted in monsoonal winds with enhanced northerly and westerly components

While a multi-day biomass burning event was observed, in comparison to 2011, aerosol events showed much higherfrequency behavior. Even in the middle of the Sulu Sea, pulses of aerosol particles on the order of 3-6h were observed. This behavior is likely in part due to influence of scattered convection, leaving pockets of polluted and clean air masses. In addition, the aforementioned nucleation events and urban plumes added additional high-frequency signals. This high-frequency behavior further complicates an already complex aerosol and cloud system and specifically hinders interpretation of temporally discrete measurements.

The 2011 cruise pointed to the important role of organized squall lines and cold pools in scavenging aerosol particles from the marine boundary layer. While very clean air was observed behind the squall lines, there were many cases in the 2012 cruise where the opposite relationship was observed; that is, a rapid temperature drop and spike in wind heralded not clean air behind a squall line, but highly polluted air. This difference may be a result of squall line origin, meteorology, 
and/or life cycle. Some of the effects may be a result of remnant cold pools. Alternatively, the steering winds and wind shear may have been such that some moisture convergence occurred on the leading edge of an ejection event, leading to weaker convection along the boundary. However, our prevailing hypothesis is that these events are a result of convection forming from a coastal land breeze ejection event that is caught in enhanced monsoonal flows. Clearly, understanding the dynamics of aerosol particles around such organized convective features is a high priority for future work.

Finally, taken together, the 2011 and 2012 cruises cast doubt on our ability to deterministically predict or characterize the complex aerosol and cloud environment in tropical regions, particularly around the MC. While the dynamics that set the large-scale context are generally well characterized (e.g., TCs, the SWM, and convectively coupled waves in general), the specifics of aerosol burden, chemistry, and microphysics are in no small part determined by high-frequency events that are challenging to observe and to model. Indeed, outstanding science questions exist on how polluted air masses transform into cleaner ones. Additionally, aerosol flows around individual cloud features are a key priority for measurements in the future. Such issues need to be considered at the heart of future mission requirements such as for ACE.

\section{Data availability}

NASA MODIS AOT data were obtained from the NASA LAADS ftp site: ftp://ladsweb.nascom.nasa.gov/. NASA AERONET data are available from the AERONET website: http://aeronet.gsfc.nasa.gov/. Navy NAAPS aerosol reanalysis and meteorology data are available at the US GODAE server: http://www.usgodae.org/. Vasco ship data and MTSAT imagery are available through correspondence with the author, jeffrey.reid@nrlmry.navy.mil.

Acknowledgements. Organization of this research cruise and the overall 2012 IOP required the assistance of a number of organizations, including the staff of the Office of Naval ResearchGlobal program office and reservist unit (esp. Joseph Johnson, Blake McBride, and Paul Marshall), the Manila Observatory (esp. Antonia Loyzaga and Fr. Daniel McNamara), US State Department/Embassy in Manila (esp. Maria Theresa Villa and Dovas Saulys), and the Naval Postgraduate School (esp. Richard Lind). We are most grateful to the Vasco ship management and crew, operated by Cosmix Underwater Research Ltd. (esp. Luc Heymans and Annabelle du Parc). We are also grateful to the host institutions for regional AERONET site deployment and the use of derived optical thickness data herein. Authors also benefitted from conversations with Eric Maloney (CSU) and Matthew Wheeler (CSIRO). Funding for this research cruise and analysis was provided by numerous sources. Vasco ship time procurement was provided by the NRL 6.1 Base Program via an ONR Global grant to the Manila Observatory. Funding for US scientist deployment and instrument analysis was provided by the NRL Base Program and ONR 35. Modeling analysis was provided by ONR 32. Remote sensing and model analysis was provided by the NASA Interdisciplinary Science Program. Reservist support was provided by ONR Program 38. Ground site deployments were supported by the NASA Radiation Science Program through a grant from the Southeast Asia Composition, Cloud, Climate Coupling Regional Study (SEAC ${ }^{4} \mathrm{RS}$ ) science team. Gas chemistry was provided by the NASA Tropospheric Chemistry Program. Author James R. Campbell acknowledges the support of NASA Interagency Agreement NNG13HH10I on behalf of MPLNET and $\mathrm{SEAC}^{4} \mathrm{RS}$ science teams.

Edited by: F. Yu

Reviewed by: R. Swap and two anonymous referees

\section{References}

Akagi, S. K., Yokelson, R. J., Wiedinmyer, C., Alvarado, M. J., Reid, J. S., Karl, T., Crounse, J. D., and Wennberg, P. O.: Emission factors for open and domestic biomass burning for use in atmospheric models, Atmos. Chem. Phys., 11, 4039-4072, doi:10.5194/acp-11-4039-2011, 2011.

Anderson, T. L., Covert, D. S., Marshall, S. F., Laucks, M. L., Charlson, R. J., Waggoner, A. P., Ogren, J. A., Caldow, R., Holm, R. L., Quant, F. R., Sem, G. J., Wiedensohler, A., Ahlquist, N. A., and Bates, T. S.: Performance characteristics of a highsensitivity three wavelength, total, backscatter nephelometer, J. Atmos. Ocean Tech., 13, 967-986, 1996.

Andreae, M. O., Rosenfeld, D., Artaxo, P., Costa, A. A., Frank, G. P., Longo, K. M., Silva-Dias, MAF, Smoking rain clouds over the Amazon, Science, 303, 1337-1342, doi:10.1126/science.1092779, 2004.

Atwood, S. A., Reid, J. S., Kreidenweis, S. M., Yu, L. E., Salinas, S. V., Chew, B. N., and Balasubramanian, R.: Analysis of source regions for smoke events in Singapore for the 2009 El Niño burning season, Atmos. Environ., 78, 219-230, doi:10.1016/j.atmosenv.2013.04.047, 2013.

Atwood, S. A., Reid, J. S., Kreidenweis, S. M., Blake, D. R., Jonsson, H. H., Lagrosas, N. D., Lynch, P., Reid, E. A., Sessions, W. R., and Simpas, J. B.: Size-resolved aerosol and cloud condensation nuclei $(\mathrm{CCN})$ properties in the remote marine South China Sea, Part 1: Observations and source classification, Atmos. Chem. Phys. Discuss., doi:10.5194/acp-2016-645, in review, 2016

Beegum, S. N., Krishna Moorthy, K., Babu, S. S., Reddy, R. R., and Gopal, K. R.: Large scale modulations of spectral aerosol optical depths by atmospheric planetary waves, Geophys. Res. Lett., 36, L03810, doi:10.1029/2008GL036509, 2009.

Betha, R., Spracklen, D. V., and Balasubramanian, R.: Observations of new aerosol particle formation in a tropical urban atmosphere, Atmos. Environ., 71, 340-351, doi:10.1016/j.atmosenv.2013.01.049, 2013.

Brines, M., Dall'Osto, M., Beddows, D. C. S., Harrison, R. M., Gómez-Moreno, F., Núñez, L., Artíñano, B., Costabile, F., Gobbi, G. P., Salimi, F., Morawska, L., Sioutas, C., and Querol, $\mathrm{X}$. : Traffic and nucleation events as main sources of ultrafine par- 
ticles in high-insolation developed world cities, Atmos. Chem. Phys., 15, 5929-5945, doi:10.5194/acp-15-5929-2015, 2015.

Bond, T. C., Anderson, T. L., and Campbell, D.: Calibration and intercomparison of filter based measurements of visible light absorption by aerosols, Aerosol Sci. Tech., 30, 582-600, doi:10.1080/027868299304435, 1999.

Boy, M., Karl, T., Turnipseed, A., Mauldin, R. L., Kosciuch, E., Greenberg, J., Rathbone, J., Smith, J., Held, A., Barsanti, K., Wehner, B., Bauer, S., Wiedensohler, A., Bonn, B., Kulmala, M., and Guenther, A.: New particle formation in the Front Range of the Colorado Rocky Mountains, Atmos. Chem. Phys., 8, 15771590, doi:10.5194/acp-8-1577-2008, 2008.

Cahill, T. A., Goodart, C., Nelson, J. W., Eldred, R. A., Nasstrom, J. S., and Feeny, P. J.: Design and evaluation of the DRUM impactor, in: Proceedings of the International Symposium on Particulate and Multiphase Processes, edited by: Ariman, T. and Veziroglu, T. N., Hemisphere Publishing Corporation, Washington, D.C., 319-325, 1985

Campbell, J. R., Reid, J. S., Westphal, D. L., Zhang, J., Tackett, J. L., Chew, B. N., Welton, E. J., Shimizu A., and Sugimoto, N.: Characterizing aerosol particle composition and the vertical profile of extinction and linear depolarization over Southeast Asia and the Maritime Continent: the 2007-2009 view from CALIOP, Atmos. Res., 122, 520-543, doi:10.1016/j.atmosres.2012.05.007, 2013.

Chow, J. C., Watson, J. G., Pritchett, L. C., Pierson, W. R., Frazier, C. A., and Purcell, R. G.: The DRI thermal/optical analysis system: Description, evaluation and applications in U.S. air quality studies, Atmos. Environ., 27A, 1185-1201, 1993.

Cheung, H. C., Morawska, L., and Ristovski, Z. D.: Observation of new particle formation in subtropical urban environment, Atmos. Chem. Phys., 11, 3823-3833, doi:10.5194/acp-11-38232011, 2011.

Colman, J. J., Swanson, A. L., Meinardi, S., Sive, B. B., Blake, D. R., and Rowland, F. S.: Description of the analysis of a wide range of volatile compounds in whole air samples collected during PEM-Tropics A and B, Anal. Chem., 73, 3723-3731, 2001.

Covert, D. S., Kapustin, V. N., Quinn, P. K., and Bates, T. S.: New particle formation in the marine boundary layer, J. Geophys. Res., 97, 20581-20589, 1992.

Feingold, G., Remer, L. A., Ramaprasad, J., and Kaufman, Y. J.: Analysis of smoke impact on clouds in Brazilian biomass burning regions: An extension of Twomey's approach, J. Geophys. Res., 106, 22907-22922, doi:10.1029/2001JD000732, 2001.

Ferek, R. J., Reid, J. S., Hobbs, P. V., Blake, D. R., and Liousse, C.: Emission factors of hydrocarbons, halocarbons, trace gases, and particles from biomass burning in Brazil, J. Geophys. Res., 103, 32107-32118, 1998.

Field, R. D. and Shen, S. S. P.: Predictability of carbon emissions from biomass burning in Indonesia, J. Geophys. Res., 113, G04024, doi:10.1029/2008JG000694, 2008.

Ge, C., Wang, J., and Reid, J. S.: Mesoscale modeling of smoke transport over the Southeast Asian Maritime Continent: coupling of smoke direct radiative effect below and above the low-level clouds, Atmos. Chem. Phys., 14, 159-174, doi:10.5194/acp-14159-2014, 2014.

Holben, B. N., Eck, T. F., Slutsker, I., Tanre, D., Buis, J. P., Setzer, A., Vermote, E., Reagan, J. A., Kaufman, Y. J., Nakajima, T., Lavenu, F., Jankowiak, I., and Smirnov, A.: AERONET - A federated instrument network and data archive for aerosol characterization, Remote Sens. Environ., 66, 1-16, 1998.

Hogan, T. F. and Rosmond, T. E.: The description of the U.S. Navy Operational Global Atmospheric Prediction System's spectral forecast model, Mon. Weather Rev., 119, 1786-1815, 1991.

Hu, L., Millet, D. B., Baasandorj, M., Griffis, T. J., Turner, P., Helmig, D., Curtis, A. J., and Hueber, J.: Isoprene emissions and impacts over an ecological transition region in the U.S. Upper Midwest inferred from tall tower measurements, J. Geophys. Res.-Atmos., 120, 3553-3571, doi:10.1002/2014JD022732, 2015.

Joyce, R. J., Janowiak, J. E., Arkin, P. A., and Xie, P.: CMORPH: A method that produces global precipitation estimates from passive microwave and infrared data at high spatial and temporal resolution, J. Hydrometeorol., 5, 487-503, 2004.

Kanawade, V. P., Tripathi, S. N., Siingh, D., Gautam, A. S., Srivastava, A. K., Kamra, A. K., Soni, V. K., and Sethi, V.: Observations of new particle formation at two distinct Indian subcontinental urban locations, Atmos. Environ., 96, 370-379, doi:10.1016/j.atmosenv.2014.08.001, 2014.

Kulmala, M., Vehkamaki, H., Petaja, T., Dal Maso, M., Lauri, A., Kerminen, V.-M., Birmili, W., and McMurry, P. H.: Formation and growth rates of ultrafine atmospheric particles: a review of observations, J. Aerosol Sci., 35, 143-176, 2004.

Levy, R. C., Mattoo, S., Munchak, L. A., Remer, L. A., Sayer, A. M., Patadia, F., and Hsu, N. C.: The Collection 6 MODIS aerosol products over land and ocean, Atmos. Meas. Tech., 6, 29893034, doi:10.5194/amt-6-2989-2013, 2013.

Liberti, G. L., Chéruy, F., and Desbois, M.: Land effect on the diurnal cycle of clouds over the TOGA COARE area, as Observed from GMS IR Data, Mon. Weather Rev., 129, 1500-1517, 2001.

Lin, N.-H., Si-Chee Tsay, S.-C., Maring, H. B., Yen, M.-C., Sheu, G.-R., Wang, S.-H., Chi, K.-H., Chuang, M.-T., Ou-Yang, C.-F., Fu, J. S., Reid, J. S., Lee, C.-T., Wang, L.-C., Wang, J.-L., Hsu, C. N., Sayer, A. M., Holben, B. N., Yu-Chi Chu, T.-C., Nguyen, X. A., Sopajaree, K. S., Chen, S.-J., Cheng, M.-T., Tsuang, B.J., Tsai, C.-J., Peng, C.-M., Schnell, R. C., Conway, T., Chang, C.-T., Lin, K.-S., Tsai, Y. I., Lee, W.-J., Chang, S.-C., Liu, J.J., Chiang, W.-L., Huang, S.-J., Lin, T.-H., and Liu, G. R.: An overview of regional experiments on biomass burning aerosols and related pollutants in Southeast Asia: From BASE-ASIA and the Dongsha Experiment to 7-SEAS, Atmos. Environ., 78, 1-19, 2013.

Lohmann, U. and Feichter, J.: Global indirect aerosol effects: a review, Atmos. Chem. Phys., 5, 715-737, doi:10.5194/acp-5-7152005, 2005.

Lynch, P., Reid, J. S., Westphal, D. L., Zhang, J., Hogan, T. F., Hyer, E. J., Curtis, C. A., Hegg, D. A., Shi, Y., Campbell, J. R., Rubin, J. I., Sessions, W. R., Turk, F. J., and Walker, A. L.: An 11-year global gridded aerosol optical thickness reanalysis (v1.0) for atmospheric and climate sciences, Geosci. Model Dev., 9, 14891522, doi:10.5194/gmd-9-1489-2016, 2016.

Mäkelä, J. M., Aalto, P., Jokinen, V., Pohja, T., Nissinen, A., Palmroth, S., Markkanen, T., Seitsonen, K., Lihavainen, H., and Kulmala, M.: Observations of ultrafine aerosol particle formation and growth in boreal forest, Geophys. Res. Let, 24, 1219-1222, 1997.

Maloney, E. D. and Hartman, D. L.: The Madden Julian oscillation, barotropic dynamics, and the North Pacific tropical cyclone 
formation, part 1: Observations, J. Atmos. Sci., 58, 2545-2558, 2001.

McGaughey, G. R., Desai, N. R., Allen, D. T., Seila, R. L., Lonneman, W. A., Fraser, M. P., Harley, R. A., Pollack, A. K., Ivy, J. M., and Price, J. H.: Analysis of motor vehicle emissions in a Houston tunnel during the Texas Air Quality Study 2000, Atmos. Environ., 38, 3363-3372, doi:10.1016/jatmosenv.2004.03.006, 2004.

Miller, S. D., Hawkins, J. D., Kent, J., Turk, F. J., Lee, T. F., Kuchiauskas, A. P., Richardson, K., Wade, R., and Hoffman, C.: NexSat: Previewing NPOESS/VIIRS imagery capabilities, B. Am. Meteorol. Soc., 87, 433-446, doi:10.1175/BAMS-87-4-433, 2006.

Nichol, J.: Smoke haze in Southeast Asia: A predictable recurrence, Atmos. Environ., 32, 2715-2716, 1998.

Ogren, J. A.: NOAA, in preparation, 2016.

O’Neill, N. T., Eck, T. F., Smirnov, A., Holben, B. N., and Thulasiraman, S.: Spectral discrimination of coarse and fine mode optical depth, J. Geophys. Res., 108, 4559, doi:10.1029/2002JD002975, 2003.

Petters, M. D. and Kreidenweis, S. M.: A single parameter representation of hygroscopic growth and cloud condensation nucleus activity, Atmos. Chem. Phys., 7, 1961-1971, doi:10.5194/acp-71961-2007, 2007.

Petters, M. D., Carrico, C. M., Kreidenweis, S. M., Prenni, A. J., DeMott, P. J., Collett, J. L., and Moosmüller, H.: Cloud condensation nucleation activity of biomass burning aerosol, J. Geophys. Res.-Atmos., 114, D22205, doi:10.1029/2009JD012353, 2009.

Qian, J.-H.: Why precipitation is mostly concentrated over islands in the Maritime Continent, J. Atmos. Sci., 65, 1428-1441, doi:10.1175/2007JAS2422.1, 2008

Reid, J. S., Hobbs, P. V., Ferek, R. J., Martins, J. V., Blake, D., Dunlap, M. R., and Liousse, C.: Physical, chemical and optical properties of regional hazes dominated by smoke in Brazil, J. Geophys. Res., 103, 32059-32080, doi:10.1029/98JD00458, 1998.

Reid, J. S., Hobbs, P. V., Rangno, A. L., and Hegg, D. A.: Relationships between cloud droplet effective radius, liquid water content and droplet concentration for warm clouds in Brazil embedded in biomass smoke, J. Geophys. Res., 104, 6145-6153, 1999.

Reid, J. S., Koppmann, R., Eck, T. F., and Eleuterio, D. P.: A review of biomass burning emissions part II: intensive physical properties of biomass burning particles, Atmos. Chem. Phys., 5, 799825, doi:10.5194/acp-5-799-2005, 2005.

Reid, J. S., Brooks, B., Crahan, K. K., Hegg, D. A., Eck, T. F., O'Neill, N., de Leeuw, G., Reid, E. A., and Anderson K. D.: Reconciliation of coarse mode sea-salt aerosol particle size measurements and parameterizations at a subtropical ocean receptor site, J. Geophys. Res., 111, D02202, doi:10.1029/2005JD006200, 2006.

Reid, J. S., Piketh, S., Burger, R., Ross, K., Jensen, T., Bruintjes, R., Walker, A., Al Mandoos, A., Miller, S., Hsu, C., Kuciauskas, A., and Westphal, D. L.: An overview of UAE2 flight operations: Observations of summertime atmospheric thermodynamic and aerosol profiles of the southern Arabian Gulf, J. Geophys. Res., 113, D14213, doi:10.1029/2007JD009435, 2008.

Reid, J. S., Xian, P., Hyer, E. J., Flatau, M. K., Ramirez, E. M., Turk, F. J., Sampson, C. R., Zhang, C., Fukada, E. M., and Maloney, E. D.: Multi-scale meteorological conceptual analysis of observed active fire hotspot activity and smoke optical depth in the Maritime Continent, Atmos. Chem. Phys., 12, 2117-2147, doi:10.5194/acp-12-2117-2012, 2012.

Reid, J. S., Hyer, E. J., Johnson, R. S., Holben, B. N., Yokelson, R. J., Zhang, J., Campbell, J. R., Christopher, S. A., Di Girolamo, L., Giglio, L., Holz, R. E., Kearney, C., Miettinen, J., Reid, E. A., Turk, F. J., Wang, J., Xian, P., Zhao, G., Balasubramanian, R., Chew, B. N., Janjai, S., Lagrosas, N., Lestari, P., Lin, N. H., Mahmud, M., Nguyen, A. X., Norris, B., Oanh, N. T. K., Oo, M., Salinas, S. V., Welton, E. J., and Liew, S. C.: Observing and understanding the Southeast Asian aerosol system by remote sensing: An initial review and analysis for the Seven Southeast Asian Studies (7SEAS) program, Atmos. Res., 122, 403-468, doi:10.1016/j.atmosres.2012.06.005, 2013.

Reid, J. S., Lagrosas, N. D., Jonsson, H. H., Reid, E. A., Sessions, W. R., Simpas, J. B., Uy, S. N., Boyd, T. J., Atwood, S. A., Blake, D. R., Campbell, J. R., Cliff, S. S., Holben, B. N., Holz, R. E., Hyer, E. J., Lynch, P., Meinardi, S., Posselt, D. J., Richardson, K. A., Salinas, S. V., Smirnov, A., Wang, Q., Yu, L., and Zhang, J.: Observations of the temporal variability in aerosol properties and their relationships to meteorology in the summer monsoonal South China Sea/East Sea: the scale-dependent role of monsoonal flows, the Madden-Julian Oscillation, tropical cyclones, squall lines and cold pools, Atmos. Chem. Phys., 15, 1745-1768, doi:10.5194/acp-15-1745-2015, 2015.

Reid, J. S., Xian, P., Holben, B. N., Hyer, E. J., Reid, E. A., Salinas, S. V., Zhang, J., Campbell, J. R., Chew, B. N., Holz, R. E., Kuciauskas, A. P., Lagrosas, N., Posselt, D. J., Sampson, C. R., Walker, A. L., Welton, E. J., and Zhang, C.: Aerosol meteorology of the Maritime Continent for the 2012 7SEAS southwest monsoon intensive study - Part 1: regional-scale phenomena, Atmos. Chem. Phys., 16, 14041-14056, doi:10.5194/acp16-14041-2016, 2016.

Rose, D., Nowak, A., Achtert, P., Wiedensohler, A., Hu, M., Shao, M., Zhang, Y., Andreae, M. O., and Pöschl, U.: Cloud condensation nuclei in polluted air and biomass burning smoke near the mega-city Guangzhou, China - Part 1: Size-resolved measurements and implications for the modeling of aerosol particle hygroscopicity and CCN activity, Atmos. Chem. Phys., 10, 33653383, doi:10.5194/acp-10-3365-2010, 2010.

Seigel, R. B. and van den Heever, S. C.: Dust lofting and ingestion by supercell storms, J. Atmos. Sci., 69, 1453-1473, doi:10.1175/JAS-D-11-0222.1, 2012.

Simpson, I. J., Aburizaiza, O. S., Siddique, A., Barletta, B., Blake, N. J., Gartner, A., Khwaja, H., Meinardi, S., Zeb, J., and Blake, D. R.: Air quality in Mecca and surrounding holy places in Saudi Arabia during Hajj: Initial survey, Environ. Sci. Technol., 48, 8529-8539, 2014.

Smirnov, A., Holben, B. N., Giles, D. M., Slutsker, I., O’Neill, N. T., Eck, T. F., Macke, A., Croot, P., Courcoux, Y., Sakerin, S. M., Smyth, T. J., Zielinski, T., Zibordi, G., Goes, J. I., Harvey, M. J., Quinn, P. K., Nelson, N. B., Radionov, V. F., Duarte, C. M., Losno, R., Sciare, J., Voss, K. J., Kinne, S., Nalli, N. R., Joseph, E., Krishna Moorthy, K., Covert, D. S., Gulev, S. K., Milinevsky, G., Larouche, P., Belanger, S., Horne, E., Chin, M., Remer, L. A., Kahn, R. A., Reid, J. S., Schulz, M., Heald, C. L., Zhang, J., Lapina, K., Kleidman, R. G., Griesfeller, J., Gaitley, B. J., Tan, Q., and Diehl, T. L.: Maritime aerosol network as a component of AERONET - first results and comparison with global aerosol 
models and satellite retrievals, Atmos. Meas. Tech., 4, 583-597, doi:10.5194/amt-4-583-2011, 2011.

Suess, E.: Marine cold seeps and their manifestations: geological control, biogeochemical criteria and environmental conditions, Int. J. Earth Sci., 103, 1889-1916, doi:10.1007/s00531014-1010-0, 2014.

Tian, B., Waliser, D. E., Kahn, R. A., Li, Q., Yung, Y. L., Tyranowski, T., Geogdzhayev, I. V., Mishchenko, M. I., Torres, O., and Smirnov, A.: Does the Madden-Julian Oscillation influence aerosol variability?, J. Geophys. Res., 113, D12215, doi:10.1029/2007JD009372, 2008.

Virts, K., Wallace, J. M., Hutchins, M. L., and Holzworth, R. H.: Diurnal lightning variability over the Maritime Continent: Impact of low-level winds, cloudiness, and the MJO, J. Atmos. Sci., 70, 3128-3146, doi:10.1175/JAS-D-13-021.1, 2013.

Wang, J., Gei, C., Yang, Z., Hyer, E., Reid, J. S., Chew, B. N., and Mahmud, M.: Mesoscale modeling of smoke transport over the South Asian maritime continent: vertical distributions and topographic effect, Atmos. Res., 122, 486-503, 2013.

Wiedinmyer, C., Greenberg, J., Guenther, A., Hopkins, B., Baker, K., Geron, C., Palmer, P. I., Long, B. P., Turner, J. R., Pétron, G., Harley, P., Pierce, T. E., Lamb, B., Westberg, H., Baugh, W., Koerber, M., and Janssen, M.: Ozarks Isoprene Experiment (OZIE): Measurements and modeling of the "isoprene volcano", J. Geophys. Res., 110, D18307, doi:10.1029/2005JD005800, 2005.
Xian, P., Reid, J. S., Atwood, S. A., Johnson, R., Hyer, E. J., Westphal, D. L., and Sessions, W.: Smoke transport patterns over the Maritime Continent, Atmos. Res., 122, 469-485, doi:10.1016/j.atmosres.2012.05.006, 2013.

Yu, F., Wang, Z., Luo, G., and Turco, R.: Ion-mediated nucleation as an important global source of tropospheric aerosols, Atmos. Chem. Phys., 8, 2537-2554, doi:10.5194/acp-8-2537-2008, 2008.

Yu, F., Luo, G., Bates, T., Anderson, B., Clarke, A., Kapustin, V., Yantosca, R., Wang, Y., and Wu, S.: Spatial distributions of particle number concentrations in the global troposphere: Simulations, observations, and implications for nucleation mechanisms, J. Geophys. Res., 115, D17205, doi:10.1029/2009JD013473, 2010 . 